\title{
Factors controlling shell carbon isotopic composition of land snail Acusta despecta sieboldiana estimated from laboratory culturing experiment
}

\author{
N. Zhang ${ }^{1}$, K. Yamada ${ }^{1}$, N. Suzuki ${ }^{2}$, and N. Yoshida ${ }^{1,3}$ \\ ${ }^{1}$ Department of Environmental Chemistry and Engineering, Tokyo Institute of Technology, Yokohama, Japan \\ ${ }^{2}$ Department of Geology and Paleontology, National Museum of Nature and Science, Tsukuba, Japan \\ ${ }^{3}$ Earth-Life Science Institute, Tokyo Institute of Technology, Tokyo, Japan
}

Correspondence to: N. Zhang (zhang.n.aa@m.titech.ac.jp)

Received: 8 April 2014 - Published in Biogeosciences Discuss.: 6 May 2014

Revised: 29 August 2014 - Accepted: 1 September 2014 - Published: 6 October 2014

\begin{abstract}
The carbon isotopic composition $\left(\delta^{13} \mathrm{C}\right)$ of land snail shell carbonate derives from three potential sources: diet, atmospheric $\mathrm{CO}_{2}$, and ingested carbonate (limestone). However, their relative contributions remain unclear. Under various environmental conditions, we cultured one land snail subspecies, Acusta despecta sieboldiana, collected from Yokohama, Japan, and confirmed that all of these sources affect shell carbonate $\delta^{13} \mathrm{C}$ values. Herein, we consider the influences of metabolic rates and temperature on the carbon isotopic composition of the shell carbonate. Based on results obtained from previous works and this study, a simple but credible framework is presented to illustrate how each source and environmental parameter affects shell carbonate $\delta^{13} \mathrm{C}$ values. According to this framework and some reasonable assumptions, we estimated the contributions of different carbon sources for each snail individual: for cabbage-fed $\left(\mathrm{C}_{3}\right.$ plant $)$ groups, the contributions of diet, atmospheric $\mathrm{CO}_{2}$, and ingested limestone vary in the ranges of 66-80, 16-24, and 0$13 \%$, respectively. For corn-fed $\left(\mathrm{C}_{4}\right.$ plant $)$ groups, because of the possible food stress (less ability to consume $\mathrm{C}_{4}$ plants), the values vary in the ranges of 56-64, 18-20, and 16-26\%, respectively. Moreover, according to the literature and our observations, the subspecies we cultured in this study show preferences towards different plant species for food. Therefore, we suggest that the potential food preference should be considered adequately for some species in paleoenvironment studies. Finally, we inferred that only the isotopic exchange of the calcite- $\mathrm{HCO}_{3}^{-}$-aragonite equilibrium during egg laying
\end{abstract}

and hatching of our cultured snails controls carbon isotope fractionation.

\section{Introduction}

Land snail shells are widely applied for the study of paleoenvironment and present environment characteristics because most of the species that were well preserved in Quaternary fossils still exist today (e.g., Yapp, 1979; Lecolle, 1985; Goodfriend et al., 1989; Goodfriend, 1992; Zanchetta et al. 2005; Colonese et al., 2007, 2010 and 2011; Yanes et al., 2008a, b, 2009, 2011, 2012, 2013a, b, c; Kehrwald et al., 2010; Zaarur et al., 2011). Specifically, the carbon isotopic composition ( $\delta^{13} \mathrm{C}$ value) of land snail shell carbonate is regarded as useful for reconstructing the distribution of terrestrial $\mathrm{C}_{3} / \mathrm{C}_{4}$ vegetation, which itself is related to some environmental parameters such as rainfall amounts and temperature variations (Goodfriend and Magaritz, 1987; Goodfriend, 1992; Stott, 2002; Metref et al., 2003).

Land snail shell carbon has three sources: food, atmospheric $\mathrm{CO}_{2}$, and ingested carbonate (limestone) (Goodfriend and Hood, 1983). Food sources such as plants, fungi, and other organic matter can be transformed into metabolic $\mathrm{CO}_{2}$ in the body of a land snail by two pathways: direct digestion and breakdown of urea (Stott, 2002). The resulting $\mathrm{CO}_{2}$ will dissolve into the bicarbonate pool in the hemolymph and then precipitate as shell carbonate. Atmospheric $\mathrm{CO}_{2}$ can be introduced into the bicarbonate pool via 
respiration. Similarly, ingested carbonate can first dissolve in stomach acid to produce gaseous $\mathrm{CO}_{2}$. Then it can be introduced into the bicarbonate pool too. Some previous works have been undertaken to clarify their relative contributions both from observations and model calculations. Nevertheless, this topic remains poorly understood (Goodfriend and Hood, 1983; Goodfriend and Stipp, 1983; Stott, 2002; Metref et al., 2003; Balakrishnan and Yapp, 2004; Romaniello et al., 2008). The following are estimations of each carbon source based on published works: food source ratios vary in the range of 25-40\% (Goodfriend and Hood, 1983), 36-73\% (Romaniello et al., 2008), and $100 \%$ (Stott, 2002; Metref et al., 2003); atmospheric $\mathrm{CO}_{2}$ has been estimated as negligible (Stott, 2002; Metref, 2003), 16-48 \% (Romaniello et al., 2008), and 30-60\% (Goodfriend and Hood, 1983); ingested carbonate has been estimated as up to $30 \%$ (Goodfriend and Stipp, 1983), often negligible for small terrestrial gastropods of less than $10 \mathrm{~mm}$, and as always much less than 20-30\% for larger species (Pigati et al., 2004, 2010), 3-23\% (Romaniello et al., 2008), and $\sim 20$ up to $\sim 40 \%$ (Yanes et al., 2008a).

For solving problems of this kind, additional studies including laboratory culturing experiments must be done. Stott (2002) and Meterf et al. (2003) reported two independent works related to land snail culture experiments. Both show a marked but discrepant correlation between land snail shell carbonate $\delta^{13} \mathrm{C}$ and diet $\delta^{13} \mathrm{C}$, with slopes less than one. Additionally, Stott pointed out that ingested carbonate does not contribute to shell carbonate $\delta^{13} \mathrm{C}$ values based on results of snails fed with and without an added $\mathrm{CaCO}_{3}$ source. Finally, according to their calculations and discussions, both papers reported that atmospheric $\mathrm{CO}_{2}$ does not contribute to shell carbonate $\delta^{13} \mathrm{C}$ values. Those reports notwithstanding, inconsistent observations and discussions emerged soon thereafter. Yanes et al. (2012) reported that higher $\delta^{13} \mathrm{C}$ values were observed during the younger growth stages of both living and fossil snails, which showed signs of a higher contribution of ingested limestone. Results of this research suggest strongly that environmental carbonate is incorporated as an important source for precipitating land snail shells (at least some snail species) and suggest that it can affect their shell $\delta^{13} \mathrm{C}$ values. Regarding the atmospheric $\mathrm{CO}_{2}$, after summarizing the previous studies of the relationship between land snail shell carbonate $\delta^{13} \mathrm{C}$ and shell organics/body tissue organics/diet (Stott, 2002; Goodfriend and Ellis, 2002; Balakrishnan and Yapp, 2004), McConnaughey and Gillikin (2008) pointed out that the offsets between $\delta^{13} \mathrm{C}$ of shell carbonate and their diet (or body organics) are greater when the $\delta^{13} \mathrm{C}$ of the latter diverge more from atmospheric $\mathrm{CO}_{2}$, suggesting that the atmospheric $\mathrm{CO}_{2}$ does contribute to shell carbonate.

These great discrepancies from reports of the literature are probably attributable to (1) the variation of land snail species studied with different ecological requirements, ethology, and other species-dependent behavior; (2) the variation of environmental conditions where these snails were living (e.g.,
$\mathrm{CaCO}_{3}$-rich areas vs. $\mathrm{CaCO}_{3}$-poor areas, wet areas vs. dry areas, hot/warm areas vs. cold/cool areas); (3) the limitations of calculations. Therefore, a better understanding of the contribution of each carbon source and related environmental controlling factors can promote this isotopic tool in the field of paleoenvironment reconstruction. For this study, we cultured one land snail subspecies (Acusta despecta sieboldiana) under different controlled conditions. Based on previous works and results of this study, a simple but credible framework was raised to discuss the mechanism of how each possible source and environmental parameter can affect shell carbonate $\delta^{13} \mathrm{C}$ values. According to this framework and some reasonable assumptions, we estimated the contributions of different carbon sources for each snail individual. This report is the first to describe an attempt at estimating the contributing proportion of limestone ingested by snail individuals using stable isotope values compared with a previous method using calculations including radiocarbon dating (Goodfriend and Stipp, 1983; Romaniello et al., 2008; Pigati et al., 2010).

\section{Materials and methods}

\subsection{Culturing of land snails}

Land snail Acusta despecta, with the Japanese name Usukawa-maimai, is widely distributed around Japan (except Hokkaido (Azuma, 1995)) and Korea (Lee and Kwon, 1996). This species is regarded as very useful for reconstructing the paleoenvironment of the Japanese archipelago from the late Pleistocene Epoch because their fossils have been found in Okinawa (3370 BP, Takamiya and Meighan, 1992) and many other islands in southern Japan (e.g., 3000-2000 BP, Fujie, 2000a; 38 000-35000 BP, Fujie, 2000b). As a common species in Japan, their physiology and ecology have been well researched in the literature (e.g., Sumikawa, 1962; Kohno, 1976; Okuma, 1982; Takahashi et al., 1992). Generally speaking, they mainly consume fresh plants (Suzuki and Yamashita, 1967; Takeuchi and Tamura, 1995) and live at temperatures of $15-30^{\circ} \mathrm{C}$ (with a broader range in nature) with the optimum temperatures of $25-30^{\circ} \mathrm{C}$ (Kohno, 1976). Typically, the Acusta despecta lifespan is around 1 year. Individuals become adults 6 months from birth (Sumikawa, 1962; Okuma, 1982; Takahashi et al., 1992).

In this study, eight adult snails of Acusta despecta sieboldiana (a subspecies of Acusta despecta) were collected in Suzukakedai, Yokohama, Japan and were cultured at room temperature (ca. $25^{\circ} \mathrm{C}$ ) beginning in January 2012. These snails began to lay eggs in March 2012. The eggs were transferred into a stainless steel container and were covered with moist cloth in a $25^{\circ} \mathrm{C}$ incubator. Most eggs hatched at around 3-4 weeks.

Larvae were distributed randomly into around 30 small transparent plastic boxes that had been perforated to allow air and vapor exchange: each box contained 3-5 snails. Some 

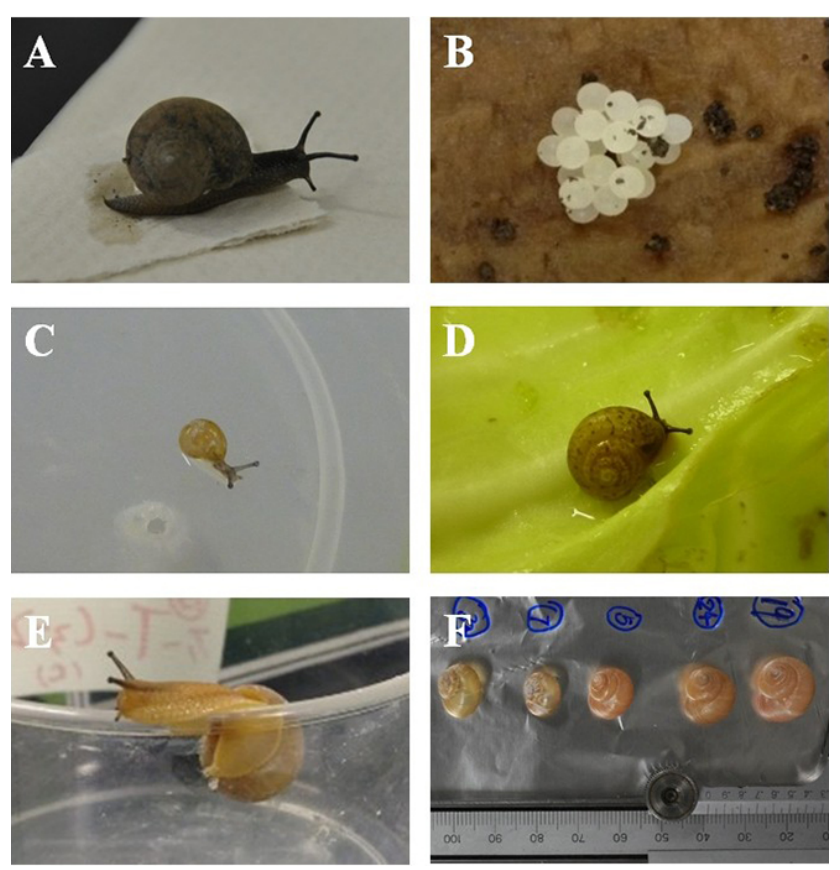

Figure 1. Growth phases of Acusta despecta sieboldiana: (a) adult snails collected from Suzukakedai, Yokohama, Japan (length: ca. 10-17 mm); (b) eggs (ca. $2 \mathrm{~mm}$ ); (c) larva (1-3 days, ca. $2 \mathrm{~mm}$ ); (d) juvenile (3-4 months, ca. 5-8 mm); (e) adult/juvenile (>6 months, > $10 \mathrm{~mm}$ ); (f) shells used for isotopic measurement.

later-hatched larvae were added in May and June 2012. Then four small boxes were put into semi-sealed big plastic boxes: two parallel groups were fed cabbage (Brassica oleracea var. capitata, green cabbage, $\mathrm{C}_{3}$ plant, $\delta^{13} \mathrm{C}=-28.4 \pm 1.2 \%$, $n=12)$ that had been sprinkled with fine calcium carbonate powder $\left(\mathrm{CaCO}_{3}, \delta^{13} \mathrm{C}=4.0 \%\right.$ ) . Another two were fed cabbage sprinkled with calcium phosphate $\left(\mathrm{Ca}_{3}\left(\mathrm{PO}_{4}\right)_{2}\right)$. A $\mathrm{NaCl}$ saturated solution was used to produce high humidity conditions in each large box. The snails grew under natural light/dark cycles. The air and food were changed every 2 days. Then the big plastic boxes were put into three incubators with respective temperatures of 20,25 , and $30^{\circ} \mathrm{C}$, until January 2013; some snails from $20^{\circ} \mathrm{C}$ group were cultured until May 2013. At the end of culturing period, we recorded the length and height for each snail (see Table S2 in the Supplement). Additionally, we checked the growth stage of one individual cultured at $25^{\circ} \mathrm{C}$ (S43, Table S2). Its length was $10.1 \mathrm{~mm}$. The results suggest that this snail had already become an adult. Consequently, the lengths for most other snails were larger than $10.0 \mathrm{~mm}$, suggesting that they had probably reached adult stage. The growth phases of snails are presented in Fig. 1.

We also cultured some snails using corn $\left(\mathrm{C}_{4}\right.$ plant, $\delta^{13} \mathrm{C}$ $=-12.0 \pm 0.7 \%, n=4$; first we used Miscanthus sinensis, but the snails did not eat it; then we changed the food to corn) sprinkled with fine calcium carbonate powder in a $20^{\circ} \mathrm{C}$ incubator.
Ultimately, the snails were collected into labeled sampling bottles and were preserved at $-40{ }^{\circ} \mathrm{C}$ for additional treatment.

\subsection{Isotopic samples preparation and analysis}

Frozen snails were dried using a cryogenic vacuum line. They were then washed with distilled water and were kept in the water for $10 \mathrm{~min}$. The soft body tissues of respective snails were separated from shells using a nipper causing no damage. Then they were immersed into $3 \mathrm{~N} \mathrm{HCl}$ for $2-4 \mathrm{~h}$, rinsed with distilled water and then lyophilized. All dry tissues were ground to powder and were wrapped in tinfoil (Sn) capsules. Samples were introduced into a combustion tube from the auto-sampler one by one and were converted into gaseous $\mathrm{CO}_{2}$ at $980^{\circ} \mathrm{C}$. Then the resultant $\mathrm{CO}_{2}$ was injected into a cavity ring-down spectroscope (CRDS, L1121I; Picarro, Inc., Santa Clara, CA, USA) for $\delta^{13} \mathrm{C}$ measurement. More details related to the CRDS method and system were presented by Wahl et al. (2006) and Balslev-Clausen et al. (2013). All measured $\delta^{13} \mathrm{C}$ values were normalized against two simultaneously measured standards, acetanilide $\left(\delta^{13} \mathrm{C}=-33.62 \%\right.$; Costech Analytical Technologies, Inc., Valencia, CA, USA $)$ and sucrose $\left(\delta^{13} \mathrm{C}=-13.55 \%\right.$; Kanto Chemical Co., Inc., Tokyo, Japan) using a two-point calibration method (Coplen et al., 2006). The analytical precision was better than $0.4 \%$ o $(n=3)$.

Shells were washed successively with distilled water, then with acetone under an ultrasonic bath for $60 \mathrm{~min}$ to eliminate the organic residues. After washing again using distilled water, they were put into labeled sampling bottles containing diluted hydrogen peroxide $(10 \%)$ to remove the remaining organic matter. These bottles were kept overnight in a shaking machine with a speed around $100 \mathrm{rpm}$. Finally, all the shells were dried using lyophilization and were crushed into a homogeneous powder using an agate mortar for isotopic analyses. The first two internal spirals were removed, which were inherited from their parents and which accounted for less than $5 \%$ of the total shell mass. Regarding the collected adults and cultured snails, their shell powder $(7-10 \mathrm{mg})$ was reacted with $103 \%$ phosphoric acid for more than $2 \mathrm{~h}$ in a $25^{\circ} \mathrm{C}$ water bath. Then the purified $\mathrm{CO}_{2}$ was analyzed using isotope ratio mass spectrometry (MAT 253; Thermo Fisher Scientific Inc., Waltham, MA, USA) and calibrated against an synthetic calcium carbonate standard $\left({ }^{13} \mathrm{C}=-9.13 \%\right.$; Wako Pure Chemical Industries Ltd., Osaka, Japan). The precision was better than $0.1 \% o(n=3)$.

Regarding the larvae and eggshell, the powder $(400 \pm$ $50 \mu \mathrm{g}$ ) was reacted with $103 \%$ phosphoric acid for more than $1 \mathrm{~h}$ at $72^{\circ} \mathrm{C}$. The resultant $\mathrm{CO}_{2}$ was analyzed using an isotope ratio mass spectrometer (Delta XL; Thermo Fisher Scientific Inc., Waltham, MA, USA) coupled with a PAL auto-sampler (GCPAL; CTC Analytics AG, Zwingen, Switzerland), and a GasBench II preparation device (Thermo Fisher Scientific Inc., Waltham, MA, USA). The $\delta^{13} \mathrm{C}$ values 


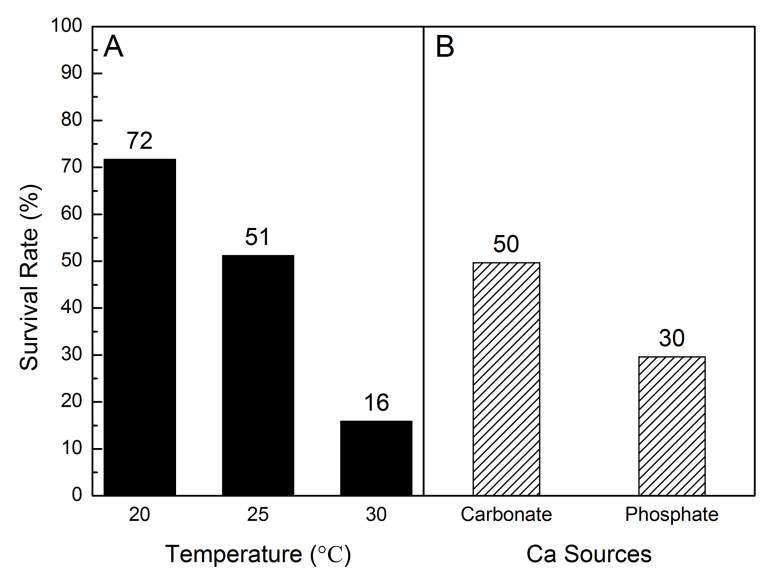

Figure 2. Snail survival rate: (a) at different temperatures; (b) with different calcium sources.

were normalized against two simultaneously measured synthetic calcium carbonate standards, Wako $\left(\delta^{13} \mathrm{C}=-9.13 \%\right.$; Wako Pure Chemical Industries Ltd., Osaka, Japan) and Kanto $\left({ }^{13} \mathrm{C}=-20.62 \%\right.$; Kanto Chemical Co., Inc., Tokyo, Japan) using two-point calibration. The analytical precision was around $0.1 \% \circ(n=3)$.

All of our in-house working standards described here are calibrated with respect to IAEA standards such as NBS-19 and the $\delta^{13} \mathrm{C}$ values are reported relative to Vienna Peedee Belemnite (VPDB).

In addition, the crystal structure of shell carbonate powder was checked using $x$ ray diffractometry (XRD, MXP3TA; Mac Science Ltd.). The results revealed that our snail shell carbonate is aragonite, although the eggshell carbonate is calcite.

\section{Results}

\subsection{Summary of culturing experiment}

Figure 2a shows that snails that grew at low temperature $\left(20^{\circ} \mathrm{C}\right)$ have a higher survival rate $(72 \%)$ than those at $30^{\circ} \mathrm{C}(16 \%)$, which is consistent to the observations by Kohno (1976). The reason is probably that, in hightemperature groups, the humidity is slightly higher so that the leaves are more easily putrefied. Because the cultured environment is a sealed system with an air exchange every 2 days, the perishable leaves consumed oxygen and perhaps produced noxious gases, which might have caused all the snails in one small box to have died. Therefore, these snails show higher mortality.

Egonmwan (2008) reported a positive correlation between calcium provision, snail body weight, and shell length. High mortality was observed for snails that were deprived of a calcium source. Similarly, in our study, snails fed $\mathrm{Ca}_{3}\left(\mathrm{PO}_{4}\right)_{2}$ exhibited lower weight and shorter length. They were more translucent, more fragile, and had thinner shells than snails fed $\mathrm{CaCO}_{3}$ during our cultivation. Moreover, Fig. $2 \mathrm{~b}$ shows a lower survival rate $(30 \%)$ of snails fed $\mathrm{Ca}_{3}\left(\mathrm{PO}_{4}\right)_{2}$ than those fed $\mathrm{CaCO}_{3}(50 \%)$, which is consistent with results of the previous study, suggesting that calcium from the powder of $\mathrm{Ca}_{3}\left(\mathrm{PO}_{4}\right)_{2}$ was ingested only to a slight degree by land snails.

For the cabbage groups, shell weight proportions of the snails, which is equal to the mass of dry shell divided by their total body mass, cultured with $\mathrm{CaCO}_{3}$ at different temperature are $27.5 \pm 2.7 \%\left(20^{\circ} \mathrm{C}\right), 31.1 \pm 6.1 \%\left(25^{\circ} \mathrm{C}\right), 17.9 \pm$ $5.5 \%\left(30^{\circ} \mathrm{C}\right)$. Those without $\mathrm{CaCO}_{3}$ are $7.8 \pm 2.9 \%\left(20^{\circ} \mathrm{C}\right)$, $5.7 \pm 1.8 \%\left(25^{\circ} \mathrm{C}\right)$, respectively. That discrepancy also reveals worse growth conditions at $30^{\circ} \mathrm{C}$ among the temperatures discussed above. Those without $\mathrm{CaCO}_{3}$ can obtain only a very small amount of calcium from either $\mathrm{Ca}_{3}\left(\mathrm{PO}_{4}\right)_{2}$, drinking water, or diet. Regarding the corn groups, preliminary results demonstrate that the snails probably have a higher shell weight proportion than those fed with cabbage ( $t$ test, $p<0.01$ ): $34.7 \pm 0.3 \%$ (corn, $\mathrm{CaCO}_{3}, 20^{\circ} \mathrm{C}$ ) vs. $27.5 \pm 2.7 \%$ (cabbage, $\mathrm{CaCO}_{3}, 20^{\circ} \mathrm{C}$ ).

\subsection{Carbon isotope results}

Body tissues of cultured snails yield a similar $\delta^{13} \mathrm{C}$ value with the same food source (Table 1), which are $-27.9 \pm$ $0.6 \%$ (fed cabbage, $n=38$ ) and $-10.8 \pm 0.7 \%$ (fed corn, $n=3$ ). No marked differences were found among temperatures or between those fed with and without $\mathrm{CaCO}_{3}$.

Shell carbonate of cultured snails fed cabbage and $\mathrm{CaCO}_{3}$ under 20,25 and $30^{\circ} \mathrm{C}$, respectively, yielded $\delta^{13} \mathrm{C}$ values of $-9.7 \pm 0.5,-10.4 \pm 0.8$, and $-13.2 \pm 0.8 \%$ (Table 1 , Fig. 6a). Those fed cabbage and $\mathrm{Ca}_{3}\left(\mathrm{PO}_{4}\right)_{2}$, respectively, yielded values of $-12.5 \pm 0.4,-13.7 \pm 0.7$, and $-14.2 \%$. Snails fed corn and $\mathrm{CaCO}_{3}$ at $20^{\circ} \mathrm{C}$ yielded a value of $3.9 \pm 0.5 \%$.

We also measured the $\delta^{13} \mathrm{C}$ values of collected adult snails, newly hatched snails, and eggshells; the results are, respectively, $-11.5 \pm 1.2 \%$ o $(n=6),-11.0 \pm 0.1 \%$ (mixed samples, $n>10$ ), $-13.1 \pm 0.9 \%$ (two groups of eggs, for each group, $n>10$ ).

\section{Discussion}

\subsection{Land snail shell carbonate precipitation and carbon source estimation}

The solid line of Fig. 3 shows a model of diet-controlled snail shell carbonate $\delta^{13} \mathrm{C}$ (Francey, 1983; Stott, 2002), whereas the dashed line shows a flux balance model based on $\mathrm{CO}_{2}$ diffusion when the input flux of $\mathrm{CO}_{2}$ is equal to respired flux of $\mathrm{CO}_{2}$ in the body fluid of land snails (Balakrishnan and Yapp, 2004). However, additional enrichments were observed in the published results and in this study (e.g., snails cultured at 20 and $25^{\circ} \mathrm{C}$ with carbonate), suggesting a contribution 
Table 1. Stable isotope results of snails cultured under different conditions and the estimated contributions of their shell carbon sources.

\begin{tabular}{|c|c|c|c|c|c|c|c|c|c|c|}
\hline $\begin{array}{l}\text { Snail } \\
\text { No. }\end{array}$ & $\begin{array}{l}\text { Temp. } \\
\left({ }^{\circ} \mathrm{C}\right)\end{array}$ & $\mathrm{CaCO}_{3}{ }^{\mathrm{a}}$ & Diet & $\begin{array}{r}\text { Diet } \\
\delta^{13} \mathrm{C}(\% o)\end{array}$ & $\begin{array}{r}\text { Shell } \\
{ }^{13} \mathrm{C}(\% o)\end{array}$ & $\begin{array}{r}\text { Tissue } \\
{ }^{13} \mathrm{C}(\% o)\end{array}$ & $\begin{array}{l}x^{*} \\
(\%)\end{array}$ & $\begin{array}{r}y^{*} \\
(\%)\end{array}$ & $\begin{array}{r}z^{*} \\
(\%)\end{array}$ & $\begin{array}{r}\text { Shell weight } \\
\text { proportion (\%) }\end{array}$ \\
\hline S1 & 20 & + & Cabbage & -28.4 & -9.6 & -28.4 & 67.7 & 21.2 & 11.1 & 30.1 \\
\hline S2 & 20 & + & Cabbage & -28.4 & -9.1 & -28.6 & 66.0 & 20.6 & 13.3 & 28.3 \\
\hline S9 & 20 & + & Cabbage & -28.4 & -9.1 & -28.5 & 66.2 & 20.7 & 13.1 & 29.7 \\
\hline S10 & 20 & + & Cabbage & -28.4 & -9.7 & -28.8 & 67.3 & 21.0 & 11.7 & 27.0 \\
\hline S11 & 20 & + & Cabbage & -28.4 & -9.7 & -27.6 & 69.5 & 21.7 & 8.7 & 32.7 \\
\hline $\mathrm{S} 12$ & 20 & + & Cabbage & -28.4 & -9.5 & -27.9 & 68.4 & 21.4 & 10.3 & 25.4 \\
\hline S5 & 20 & + & Cabbage & -28.4 & -9.5 & -27.7 & 68.7 & 21.5 & 9.8 & 25.9 \\
\hline S6 & 20 & + & Cabbage & -28.4 & -9.8 & -27.4 & 70.2 & 21.9 & 7.9 & 26.4 \\
\hline S13 & 20 & + & Cabbage & -28.4 & -9.4 & -28.1 & 67.9 & 21.2 & 10.9 & 28.2 \\
\hline S14 & 20 & + & Cabbage & -28.4 & -10.2 & -27.7 & 70.7 & 22.1 & 7.2 & 23.6 \\
\hline S15 & 20 & + & Cabbage & -28.4 & -11.0 & -26.9 & 74.5 & 23.3 & 2.2 & 24.8 \\
\hline S3 & 20 & - & Cabbage & -28.4 & -13.1 & -29.4 & 74.3 & 25.7 & 0.0 & 4.6 \\
\hline S7 & 20 & - & Cabbage & -28.4 & -12.3 & -27.7 & 76.9 & 23.1 & 0.0 & 10.1 \\
\hline S8 & 20 & - & Cabbage & -28.4 & -12.3 & -27.8 & 76.6 & 23.4 & 0.0 & 8.8 \\
\hline S16 & 20 & + & Corn & -12.0 & 4.2 & -10.3 & 59.1 & 18.5 & 22.4 & 34.4 \\
\hline S17 & 20 & + & Corn & -12.0 & 4.0 & -11.6 & 56.3 & 17.6 & 26.1 & 34.9 \\
\hline S18 & 20 & + & Corn & -12.0 & 3.3 & -10.5 & 63.7 & 19.9 & 16.4 & - \\
\hline S19 & 25 & + & Cabbage & -28.4 & -9.7 & -27.5 & 69.6 & 17.4 & 12.9 & 33.1 \\
\hline S21 & 25 & + & Cabbage & -28.4 & -11.0 & -27.7 & 72.8 & 18.2 & 9.0 & 31.0 \\
\hline S25 & 25 & + & Cabbage & -28.4 & -12.1 & -28.7 & 74.1 & 18.5 & 7.4 & 19.9 \\
\hline S26 & 25 & + & Cabbage & -28.4 & -10.1 & -27.7 & 70.5 & 17.6 & 11.9 & 34.5 \\
\hline S29 & 25 & + & Cabbage & -28.4 & -10.2 & -27.3 & 71.6 & 17.9 & 10.5 & 37.8 \\
\hline $\mathrm{S} 31$ & 25 & + & Cabbage & -28.4 & -9.8 & -27.0 & 71.0 & 17.8 & 11.2 & 30.2 \\
\hline $\mathrm{S} 33^{\mathrm{b}}$ & 25 & + & Cabbage & -28.4 & -9.9 & -26.5 & 72.3 & 18.1 & 9.6 & 9.7 \\
\hline S22 & 25 & - & Cabbage & -28.4 & -14.9 & -28.5 & 83.9 & 16.1 & 0.0 & 4.3 \\
\hline S23 & 25 & - & Cabbage & -28.4 & -13.7 & -27.5 & 82.1 & 17.9 & 0.0 & 5.9 \\
\hline S27 & 25 & - & Cabbage & -28.4 & -13.6 & -28.5 & 77.3 & 22.7 & 0.0 & 5.1 \\
\hline S28 & 25 & - & Cabbage & -28.4 & -13.4 & -27.9 & 78.8 & 21.2 & 0.0 & 4.2 \\
\hline S32 & 25 & - & Cabbage & -28.4 & -13.0 & -27.7 & 77.8 & 22.2 & 0.0 & 8.7 \\
\hline S34 & 30 & + & Cabbage & -28.4 & -13.7 & -28.0 & 78.5 & 20.1 & 1.4 & 13.8 \\
\hline S35 & 30 & + & Cabbage & -28.4 & -13.5 & -27.2 & 79.6 & 20.4 & 0.0 & 18.2 \\
\hline S36 & 30 & + & Cabbage & -28.4 & -13.1 & -28.7 & 75.2 & 19.3 & 5.6 & 18.3 \\
\hline S37 & 30 & + & Cabbage & -28.4 & -13.3 & -28.3 & 76.5 & 19.6 & 3.9 & 16.2 \\
\hline S38 & 30 & + & Cabbage & -28.4 & -13.4 & -28.5 & 76.4 & 19.6 & 3.9 & 14.5 \\
\hline S39 & 30 & + & Cabbage & -28.4 & -11.4 & -27.3 & 73.3 & 18.8 & 7.9 & 31.0 \\
\hline S40 & 30 & + & Cabbage & -28.4 & -13.8 & -29.3 & 75.9 & 19.5 & 4.6 & 14.4 \\
\hline S41 & 30 & + & Cabbage & -28.4 & -13.5 & -28.0 & 77.9 & 20.0 & 2.2 & 17.1 \\
\hline $\mathrm{S} 42^{c}$ & 30 & - & Cabbage & -28.4 & -14.2 & $-28.2^{d}$ & 79.5 & 20.5 & 0.0 & 政 \\
\hline
\end{tabular}

a “_" means those fed $\mathrm{Ca}_{3}\left(\mathrm{PO}_{4}\right)_{2}$, which is probably hard and rarely ingested by snails; ${ }^{\mathrm{b}}$ snails regarded as a control group, cultured under an air-free exchange system with a small amount of soil; ${ }^{\mathrm{c}}$ mixture of four individuals cultured in the same condition (sizes are similar); ${ }^{\mathrm{d}}$ average value of snails of S34-S41;

* $x$, calculated proportion of metabolic $\mathrm{CO}_{2} ; y$, proportion of atmospheric $\mathrm{CO}_{2} ; z$, proportion of $\mathrm{CO}_{2}$ produced from ingested carbonate

from ingested carbonate. In addition, because a common model seems unsuitable for all snails because of the different metabolic rates among snail individuals growing up at different conditions (Barnhart and McMahon, 1987), the estimation of shell carbon sources for each snail is expected to be useful and necessary.

The main sources of shell carbon are diet, atmospheric $\mathrm{CO}_{2}$, and ingested carbonate (Goodfriend and Hood, 1983). A simple framework of the possible mechanisms to precipitate shell carbonate is presented in Fig. 4 based on re- sults of a previous study as well as results from the present study. Almost all of these three carbon sources are expected to transform into gaseous $\mathrm{CO}_{2}$ and then dissolve into the hemolymph of a snail (so-called bicarbonate pool) for reaching isotopic equilibrium with bicarbonate $\left(\mathrm{HCO}_{3}^{-}\right)$. The fractionation between gaseous $\mathrm{CO}_{2}$ and $\mathrm{HCO}_{3}^{-}$under equilibrium is controlled by temperature, shown as $\Delta^{13} \mathrm{C}_{\mathrm{HCO}_{3}-\mathrm{g}}=$ $-(0.114 \pm 0.003) T\left({ }^{\circ} \mathrm{C}\right)+(10.78 \pm 0.05) \%$ (Mook et al., 1974; Zhang et al., 1995; Szaran, 1997). Therefore, the 


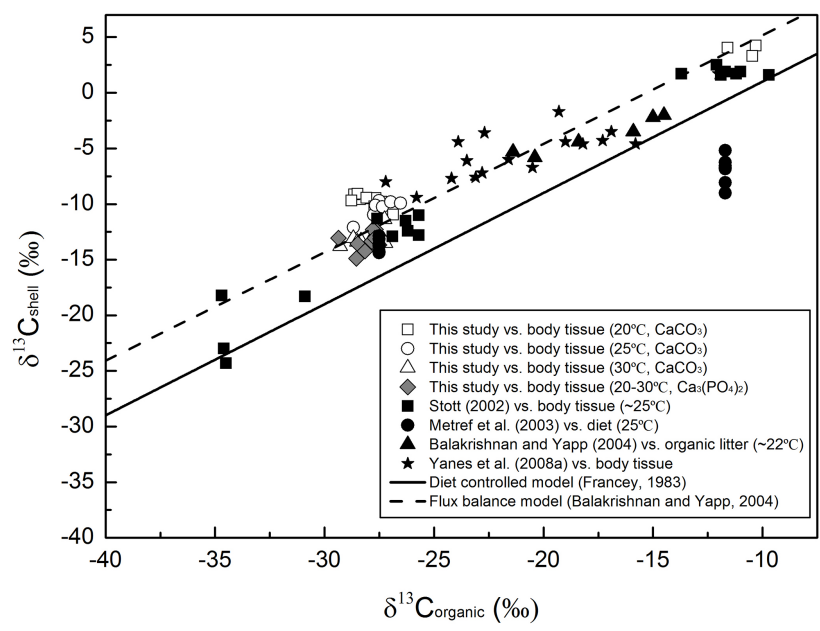

Figure 3. Measured $\delta^{13} \mathrm{C}$ of snail shell aragonite against $\delta^{13} \mathrm{C}$ of associated organic matter (This study; Stott, 2002; Metref et al., 2003; Balakrishnan and Yapp, 2004).

carbon isotope fractionations under our culturing temperatures might be $8.5,7.9$, and $7.4 \%$, respectively, at 20,25 , and $30^{\circ} \mathrm{C}$. Finally, the shell aragonite will precipitate from bicarbonate pool in isotopic equilibrium (also designated as carbon isotope steady state, Balakrishnan and Yapp, 2004) and the carbon isotope ratio might be enriched to around 2.7\%o (Rubinson and Clayton, 1969; Romanek et al., 1992). Therefore, the total fractionation between each carbon source (diet, atmospheric $\mathrm{CO}_{2}$, and ingested carbonate) and shell aragonite is expected to be an enrichment of 11.2, 10.6, and $10.1 \%$, respectively, at 20,25 , and $30^{\circ} \mathrm{C}$. In addition, trace amounts of dissolved inorganic carbonate (DIC) dissolved in leaf water and drinking water might also introduce isotopic fractionations of shell carbonate. For instance, Pigati et al. (2004), based on radiocarbon dating technique, reported that aqueous carbon sources account for approximately $10 \%$ of the shell carbon for one species of Catinella, which is a semi-aquatic gastropod. However, no report to date describes a study of this source related to terrestrial gastropods.

For simplification of the model and calculations, we made two assumptions. First, no carbon isotopic fractionation takes place when the ingested carbonate dissolves into the water and reacts with stomach acid. Second, because of the variable sources and probably low contribution of DIC from directly ingested water, which are similar to all earlier published discussions, we will not include such sources in our calculation. These assumptions can be evaluated for their propriety in future research. Results of those studies can be expected to improve the accuracy of this estimation method.

According to this framework, we will explain briefly how to calculate the contribution of each source to shell carbon based on our observed results. First, from the mass balance model, we obtain the following:

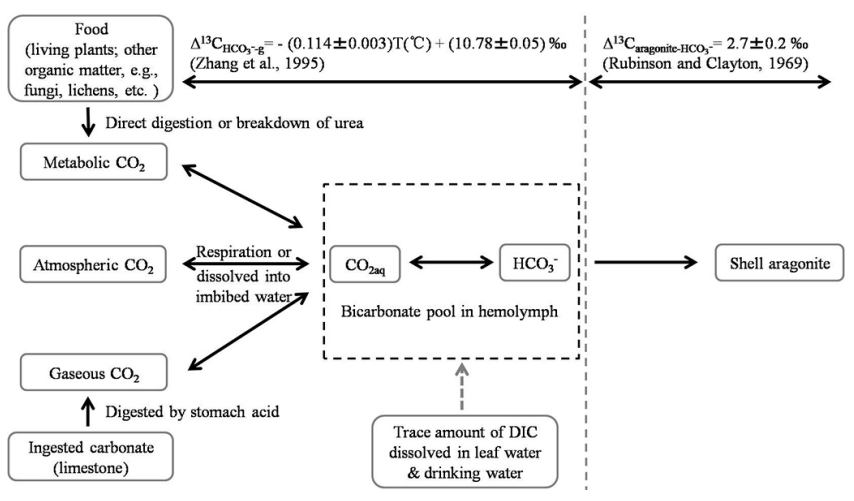

Figure 4. Simple framework of shell carbon sources and their relative isotope fractionation processes based on this and earlier studies.

$\delta^{13} \mathrm{C}_{\mathrm{S}}=x \delta^{13} \mathrm{C}_{\mathrm{t}}+y \delta^{13} \mathrm{C}_{\mathrm{a}}+z \delta^{13} \mathrm{C}_{\mathrm{c}}+b$

$x+y+z=1$

Therein, $\delta^{13} \mathrm{C}_{\mathrm{S}}$ is the isotopic composition of shell aragonite; $\delta^{13} \mathrm{C}_{\mathrm{t}}$ is the isotopic composition of snail tissue. Based on our observations and discussions (see Sect. 4.2.2), we use the measurements for each snail, not an average value, because of the individual differences among snails. $\delta^{13} \mathrm{C}_{\mathrm{a}}$ is the isotopic composition of atmospheric air $\left(\delta^{13} \mathrm{C}\right.$ of atmospheric $\mathrm{CO}_{2}$ was observed from June 2010 to July 2011 in Suzukakedai, Yokohama, Japan. The average value is $-9.5 \%$ o $(n=42$; Zhang et al., unpublished data); the annual rate of decrease reported by Keeling et al. (2010) is approximately $0.02 \% \mathrm{yr}^{-1}$. Therefore, we use $-9.5 \%$ as the $\delta^{13} \mathrm{C}_{\mathrm{a}}$ value); $\delta^{13} \mathrm{C}_{\mathrm{c}}$ is the isotopic composition of ingested carbonate $(4.0 \%) ; x$ is the proportion of metabolic $\mathrm{CO}_{2} ; y$ is the proportion of atmospheric $\mathrm{CO}_{2} ; z$ is the proportion of $\mathrm{CO}_{2}$ from ingested carbonate; $b$ is the isotope fractionation value from gaseous $\mathrm{CO}_{2}$ to aragonite at different temperatures $\left(11.2,10.6\right.$ and $10.1 \%$, at 20,25 and $30^{\circ} \mathrm{C}$, respectively).

Here we chose $20^{\circ} \mathrm{C}$ group snails to demonstrate how we calculated the contribution of each source. When there is no $\mathrm{CaCO}_{3}$ added, $z=0$.

$$
\begin{aligned}
& \delta^{13} \mathrm{C}_{\mathrm{S}}=\mathrm{x} \delta{ }^{13} \mathrm{C}_{\mathrm{t}}+(1-x) \delta^{13} \mathrm{C}_{\mathrm{a}}+11.2 \% \\
& x=\left(\delta^{13} \mathrm{C}_{\mathrm{S}}-\delta^{13} \mathrm{C}_{\mathrm{a}}-11.2\right) /\left(\delta^{13} \mathrm{C}_{\mathrm{t}}-\delta^{13} \mathrm{C}_{\mathrm{a}}\right) \cdot 100 \% \\
& x+y=1
\end{aligned}
$$

From inputting the measured data, we obtain the $x$ and $y$ values shown in Table 1. For simplification of the calculation, for the snails fed $\mathrm{CaCO}_{3}$, we assumed a similar $x / y$ ratio to those of all the snails, although individual differences 

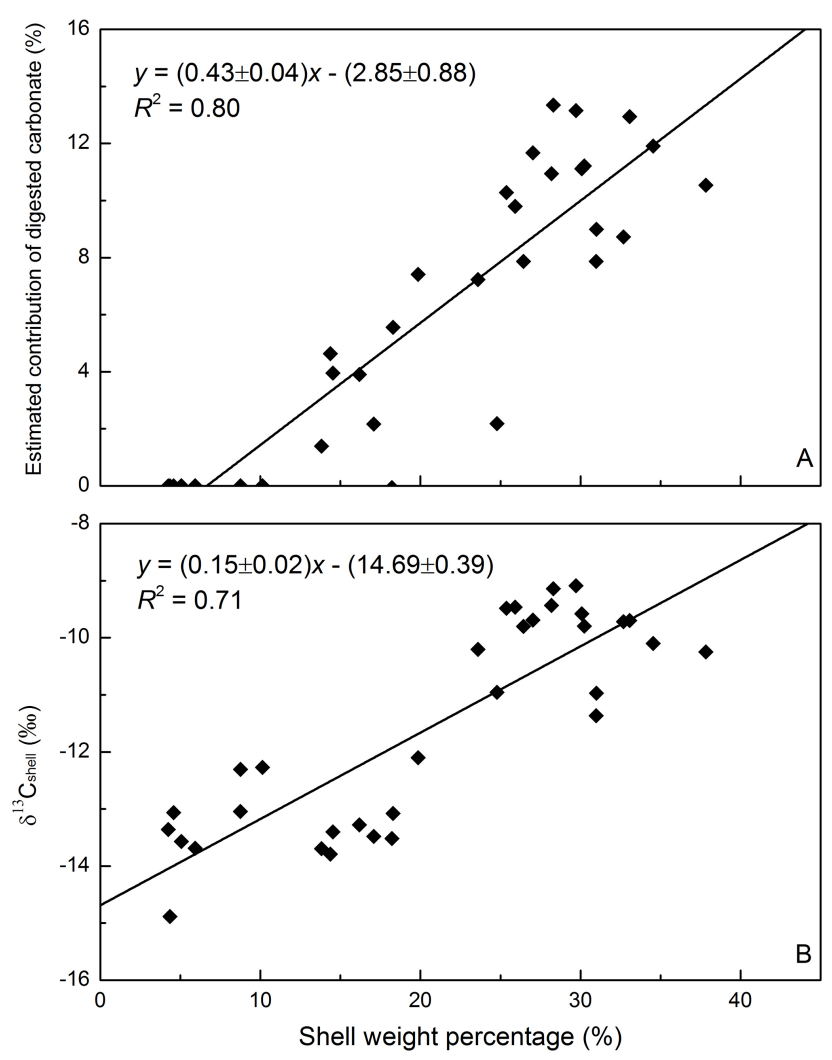

Figure 5. Relationship between (a) estimated contribution of ingested carbonate and shell weight percentage and (b) $\delta^{13} \mathrm{C}$ of snail shell aragonite and shell weight percentage.

might happen among snails attributable to different growth rates. Therefore we calculated the average $x / y$ ratio in noncarbonate groups and obtained

$x / y=3.2$

at $20^{\circ} \mathrm{C}, b=11.2 \%$. Therefore,

$y=\left(\delta^{13} \mathrm{C}_{\mathrm{S}}-\delta^{13} \mathrm{C}_{\mathrm{c}}-11.2\right) /$

$\left(3.2 \delta^{13} \mathrm{C}_{\mathrm{t}}+\delta^{13} \mathrm{C}_{\mathrm{a}}-4.2 \delta^{13} \mathrm{C}_{\mathrm{c}}\right) \cdot 100 \%$.

By combining Eqs. (2), (6), and (7), we calculated $x, y, z$ values separately. Similar calculations were done at $25^{\circ} \mathrm{C}$ and $30^{\circ} \mathrm{C}$. Finally, for the $\mathrm{C}_{4}$ plant groups, we assumed the same $x / y$ ratio for the $\mathrm{C}_{3}$ plant groups, which might not be accurate because the food consumption preference differs and $\mathrm{C}_{3}$ plant groups have a higher growth rate than $\mathrm{C}_{4}$ plant groups. Then we calculated $x, y$, and $z$ using the same method. All calculated results are presented in Table 1.

The calculated $x, y, z$ values for snails fed $\mathrm{C}_{3}$ plants reveal that the contributions of diet, atmospheric $\mathrm{CO}_{2}$, and ingested limestone varied, respectively, in the ranges 66-80, 16-24, and $0-13 \%$. Furthermore, for those fed $\mathrm{C}_{4}$ plants, because of the potential food stress (less ability to consume $\mathrm{C}_{4}$ plants), they vary in the ranges of 56-64, 18-20, and 16-26\%, respectively. We observed a higher shell weight proportion of snails that had been fed corn compared with those that had been fed cabbage, suggesting a higher ingested limestone contribution, which is coincident with our calculations.

Figure 5a presents a positive correlation between the calculated contribution of ingested carbonate and the shell weight proportion. Calcium carbonate can be transformed into $\mathrm{Ca}^{2+}$ in the stomach of land snails and can then be ingested into the hemolymph, and can finally be precipitated into the shell carbonate. Therefore, high calcium carbonate consumption is always correlated with a high shell weight proportion. The $\delta^{13} \mathrm{C}$ of fed carbonate is more positive than $\delta^{13} \mathrm{C}$ of food and atmospheric $\mathrm{CO}_{2}$. For that reason, if snails consume more carbonate, then their shell $\delta^{13} \mathrm{C}$ values are expected to be more positive, which is consistent with the relationship presented in Fig. 5b.

As described earlier, the $x / y$ ratio can vary among snail individuals. Therefore, the robustness of our estimation method was tested using the maximum and minimum $x / y$ values observed from snails fed without $\mathrm{CaCO}_{3}$ at different temperatures. The results are presented in Table 2. For snails fed with cabbage and $\mathrm{CaCO}_{3}$ at $20^{\circ} \mathrm{C}$, the $x / y$ values vary in the range of 2.9-3.3. Maximum discrepancies of estimations by the maximum and minimum $x / y$ value could be 1.3 , -2.9 , and $1.6 \%$ for $x, y$, and $z$ values, respectively. For those fed with cabbage and $\mathrm{CaCO}_{3}$ at $25^{\circ} \mathrm{C}, x / y$ values vary in the range of 3.4-5.2. Maximum discrepancies could be 3.0, -6.9 , and $4.1 \%$ for $x, y$, and $z$ values, respectively. Considering individual differences among snails (calculated standard deviations of $x, y$, and $z$ for the snails fed with cabbage and $\mathrm{CaCO}_{3}$ are 3.9, 1.6, and $3.9 \%$, respectively), these discrepancies are acceptable, especially for the estimated contribution of diet and ingested carbonate. Moreover, almost all of these re-estimated $x, y$, and $z$ values are within in the range we have calculated based on an average $x / y$ value, showing a satisfactory robustness of this estimation method.

We have become aware of another possibility for the carbon isotope fractionation related to metabolic $\mathrm{CO}_{2}$, which probably has already dissolved into the snail body water when produced with no isotope fractionation generated from gaseous state to aquatic state. In this case, the total carbon isotope fractionation values from metabolic $\mathrm{CO}_{2}$ to shell aragonite would be $12.4,11.8$, and $11.2 \%$ o, respectively, at 20,25 and $30^{\circ} \mathrm{C}$. We calculated the contributions of each carbon source using this assumption and present the results in Table S1 in the Supplement. In such circumstances, the contributions of diet, atmospheric $\mathrm{CO}_{2}$, and ingested limestone for snails fed $\mathrm{C}_{3}$ plants varied, respectively, in the ranges 70 $85,13-19$, and $0-13 \%$, whereas those fed $\mathrm{C}_{4}$ plants varied, respectively, in the ranges $64-73,15-17$, and $11-22 \%$. This estimation shows a lower contribution of atmospheric $\mathrm{CO}_{2}$ and higher contribution of diet than the previous one. Although we cannot discount either of these possibilities with present knowledge, both imply similar discussions leading to similar conclusions. Consequently, in the following discussion, we will consider only the data presented in Table 1. 
Table 2. Estimated $x, y$, and $z$ under observed maximum and minimum $x / y$ values at $20^{\circ} \mathrm{C}$ and $25^{\circ} \mathrm{C}$.

\begin{tabular}{|c|c|c|c|c|c|c|c|c|c|}
\hline Snail No. & $x_{\min }(\%)$ & $y_{\min }(\%)$ & $z_{\min }(\%)$ & $x_{\max }(\%)$ & $y_{\max }(\%)$ & $z_{\max }(\%)$ & $\Delta x(\%)$ & $\Delta y(\%)$ & $\Delta z(\%)$ \\
\hline $20^{\circ} \mathrm{C}$, Cabbage & \multicolumn{3}{|c|}{$\min : x / y=2.9$} & \multicolumn{3}{|c|}{$\max : x / y=3.3$} & & & \\
\hline S1 & 66.9 & 23.1 & 10.0 & 68.0 & 20.4 & 11.5 & 1.1 & -2.6 & 1.5 \\
\hline S2 & 65.3 & 22.5 & 12.2 & 66.3 & 19.9 & 13.8 & 1.1 & -2.6 & 1.5 \\
\hline S9 & 65.4 & 22.5 & 12.1 & 66.5 & 20.0 & 13.6 & 1.1 & -2.6 & 1.5 \\
\hline S10 & 66.5 & 22.9 & 10.6 & 67.6 & 20.3 & 12.1 & 1.1 & -2.6 & 1.5 \\
\hline S11 & 68.7 & 23.7 & 7.6 & 69.9 & 21.0 & 9.2 & 1.2 & -2.7 & 1.6 \\
\hline $\mathrm{S} 12$ & 67.5 & 23.3 & 9.2 & 68.7 & 20.6 & 10.7 & 1.1 & -2.7 & 1.5 \\
\hline S5 & 67.9 & 23.4 & 8.7 & 69.0 & 20.7 & 10.2 & 1.1 & -2.7 & 1.5 \\
\hline S6 & 69.3 & 23.9 & 6.7 & 70.5 & 21.2 & 8.3 & 1.2 & -2.7 & 1.6 \\
\hline S13 & 67.0 & 23.1 & 9.8 & 68.2 & 20.5 & 11.4 & 1.1 & -2.7 & 1.5 \\
\hline S14 & 69.8 & 24.1 & 6.1 & 71.0 & 21.3 & 7.7 & 1.2 & -2.8 & 1.6 \\
\hline S15 & 73.6 & 25.4 & 1.0 & 74.9 & 22.5 & 2.6 & 1.3 & -2.9 & 1.6 \\
\hline $20^{\circ} \mathrm{C}$, Corn & \multicolumn{3}{|c|}{$\min : x / y=2.9$} & \multicolumn{3}{|c|}{$\max : x / y=3.3$} & & & \\
\hline S16 & 57.7 & 19.9 & 22.3 & 59.6 & 17.9 & 22.5 & 1.9 & -2.0 & 0.1 \\
\hline S17 & 55.1 & 19.0 & 25.9 & 56.8 & 17.0 & 26.2 & 1.7 & -1.9 & 0.3 \\
\hline $\mathrm{S} 18$ & 62.2 & 21.5 & 16.3 & 64.2 & 19.3 & 16.5 & 2.0 & -2.2 & 0.1 \\
\hline $25^{\circ} \mathrm{C}$, Cabbage & \multicolumn{3}{|c|}{$\min : x / y=3.4$} & \multicolumn{3}{|c|}{$\max : x / y=5.2$} & & & \\
\hline S19 & 68.5 & 20.1 & 11.4 & 71.3 & 13.7 & 15.1 & 2.8 & -6.5 & 3.7 \\
\hline S21 & 71.6 & 21.1 & 7.4 & 74.5 & 14.3 & 11.3 & 2.9 & -6.8 & 3.9 \\
\hline S25 & 72.9 & 21.4 & 5.7 & 75.7 & 14.5 & 9.8 & 2.9 & -6.9 & 4.1 \\
\hline S26 & 69.3 & 20.4 & 10.3 & 72.1 & 13.8 & 14.1 & 2.8 & -6.6 & 3.8 \\
\hline S29 & 70.4 & 20.7 & 8.9 & 73.2 & 14.0 & 12.7 & 2.9 & -6.7 & 3.8 \\
\hline S31 & 69.8 & 20.5 & 9.7 & 72.7 & 13.9 & 13.4 & 2.9 & -6.6 & 3.7 \\
\hline S33 & 71.1 & 20.9 & 8.0 & 74.0 & 14.2 & 11.8 & 3.0 & -6.7 & 3.7 \\
\hline
\end{tabular}

$x_{\min }, y_{\min }$, and $z_{\min }$ are calculated using the minimum $x / y$ values; $x_{\max }, y_{\max }$, and $z_{\max }$ are calculated using the maximum $x / y$ values; $\Delta x, \Delta y$, and $\Delta z$ show the discrepancies of estimations by maximum and minimum $x / y$ values for each snail individual.

\subsection{Contribution of each carbon source to shell $\delta^{13} \mathrm{C}$}

\subsubsection{Ingested carbonate (limestone in nature)}

Stott (2002) reported no apparent differences in shell $\delta^{13} \mathrm{C}$ of land snail Helix aspersa fed with and without $\mathrm{CaCO}_{3}$. However, the deviation of ${ }^{14} \mathrm{C}$ age estimation for some snail species in nature shows an incorporation of limestone (Goodfriend and Stipp, 1983; Pigati et al., 2010). Consequently, ingested limestone is expected to play an important role in controlling shell carbonate $\delta^{13} \mathrm{C}$, at least for some species. Higher $\delta^{13} \mathrm{C}$ values were observed in our cultivated land snail Acusta despecta sieboldiana fed $\mathrm{CaCO}_{3}$ compared with those fed $\mathrm{Ca}_{3}\left(\mathrm{PO}_{4}\right)_{2}$, especially at 20 and $25^{\circ} \mathrm{C}$ (Fig. 6a). These values are even higher than the values predicted from a flux balance model (Balakrishnan and Yapp, 2004), which considers both metabolic $\mathrm{CO}_{2}$ and atmospheric $\mathrm{CO}_{2}$ (Fig. 3), strongly suggesting the involvement of ingested $\mathrm{CaCO}_{3}$ powder (Fig. 6b). The estimated contribution for $\mathrm{C}_{3}$ plant group is $0-13 \%$; and for $\mathrm{C}_{4}$ plant, it varies: $16-26 \%$. The different estimated proportions reveal different growth rates (metabolic rates) among snails. Apparently, snails fed $\mathrm{C}_{4}$ plants might prefer ingesting higher proportions of limestone, which is probably caused by diet stress.

Figure 7a (see Table 3 ) portrays a decreasing trend of shell ${ }^{13} \mathrm{C}$ along with the snail growth direction, which is consistent with the measurements of living land snail individuals reported by Yanes et al. (2012), who observed higher $\delta^{13} \mathrm{C}$ values during the younger growth stages of land snails. This fact is explainable by the larger proportion of limestone ingested during the early period of land snails to enhance their growth rates. Egonmwan (2008) reported that the amount of food ingestion increases gradually, although calcium ingestion first increases (1-3 months, but the increase rate is lower than diet consumption) and then decreases (4-6 months) during the first 6 months, suggesting that the contribution of ingested carbonate can be expected to decrease along with the snail growth. Our estimated contributions of ingested carbonate (Fig. 7b) support this presumption. To elucidate this phenomenon, similar studies should be conducted to observe snails fed with $\mathrm{C}_{4}$ plants and those fed without $\mathrm{CaCO}_{3}$. 

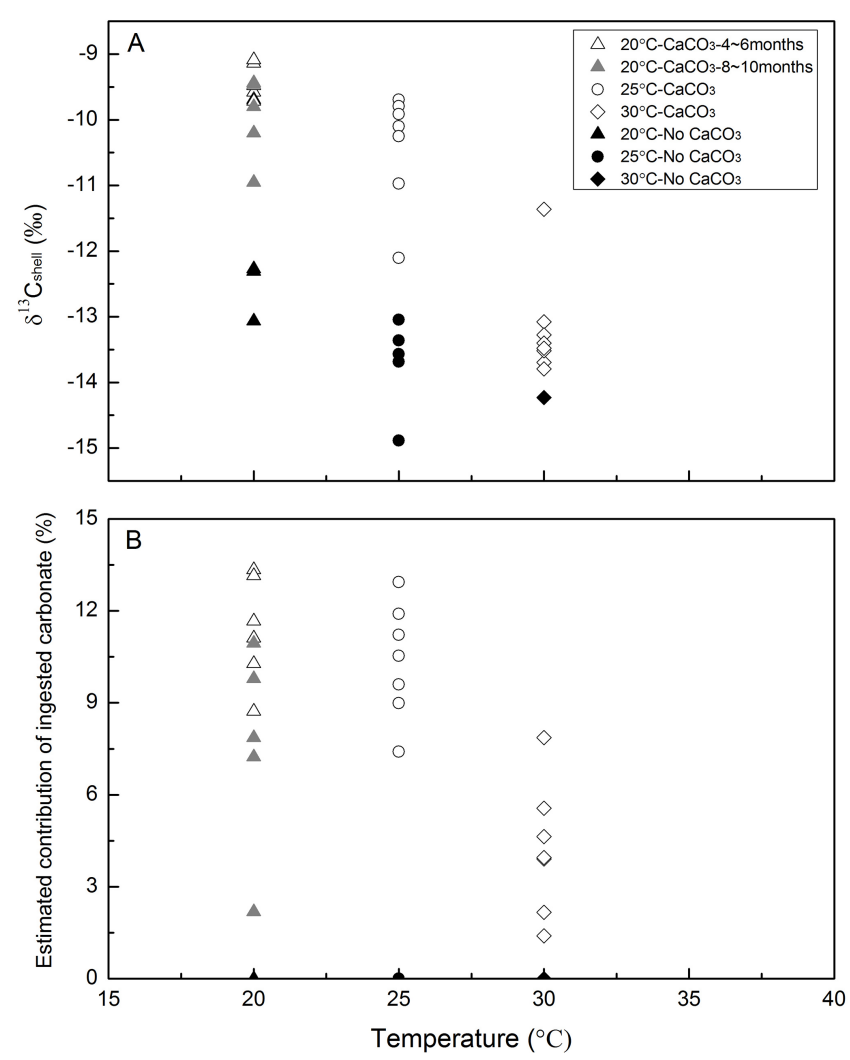

Figure 6. Bulk $\delta^{13} \mathrm{C}$ of snail shell aragonite and estimated contribution of ingested carbonate at different culturing conditions.

\subsubsection{Diet and food selectivity}

DeNiro and Epstein (1978) reported a slight enrichment (ca. $1 \%$ o) of the snail body tissue $\delta^{13} \mathrm{C}$ relative to their diet: romaine lettuce. Stott (2002) shown no significant isotopic offset between snail body tissue $\delta^{13} \mathrm{C}$ fed lettuce and their diet, whereas about 2-3\%o depletion was observed for snails fed corn (Fig. 8a), which is regarded as attributable to the contribution of pre-culture carbon because they cultured snails from juveniles but not from eggs. Our observations show slight enrichment among all snails relative to their diet: approximately $0.5 \%$ for cabbage and approximately $1.2 \%$ for corn. However, this enrichment is negligible when considering measurement precision among both snail individuals and vegetable samples. We suspect that the small discrepancies of the $\delta^{13} \mathrm{C}$ values between snail body tissue and their diet observed in the literature and this study may depend on the analytical precision and/or limitation of samples (e.g., sample size, growth condition). Therefore, we infer that the $\delta^{13} \mathrm{C}$ values of snail body tissue are similar and that they directly reflect the $\delta^{13} \mathrm{C}$ values of their food.

Figure $8 \mathrm{~b}$ shows the observed relations between shell carbonate $\delta^{13} \mathrm{C}$ of snails and their diet (This study; Stott, 2002; Metref et al., 2003). Evidently, all of these slopes are less than the expected slope of 1 , which is considering diet as a
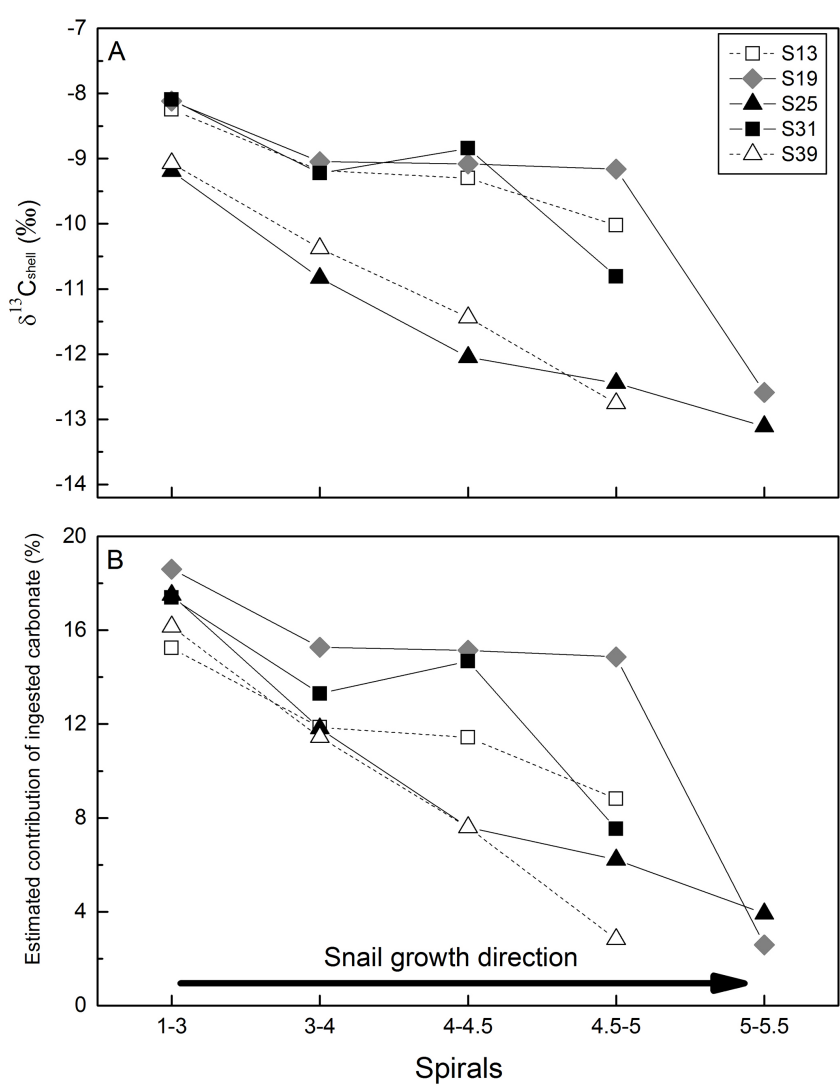

Figure 7. $\delta^{13} \mathrm{C}$ of snail shell sections and their estimated contribution of ingested carbonate at different growth phases.

single source controlling shell carbon (Francey, 1993; Stott, 2002). Offsets suggest the influence of other sources such as limestone and atmospheric $\mathrm{CO}_{2}$ cause these more positive values. The relative contributions of $\mathrm{C}_{3}$ - and $\mathrm{C}_{4}$-type food might be different. Our estimation confirms this inference: the proportions of shell carbon from cabbage are 66-80\% and from corn are 56-64\%, which might reflect food stress among different plants. Metref et al. (2003) reported a $C_{3}$ vs. $\mathrm{C}_{4}$ mixed experiment. Most snails show a preferential use of $\mathrm{C}_{3}$ food. This study also found a preference of this kind in consuming $\mathrm{C}_{3}$ but not $\mathrm{C}_{4}$ plants, e.g., snails grew faster when eating $\mathrm{C}_{3}$ plants such as lettuce and cabbage than snails fed a $\mathrm{C}_{4}$ plant such as corn, which agrees with the observations reported by Metref et al. (2003). Moreover, almost all the snails fed Miscanthus sinensis $\left(\mathrm{C}_{4}\right.$ plant) died after 20 30 days, except one or two large individuals, and their shell $\delta^{13} \mathrm{C}$ values $(-11.1 \pm 3.4 \%$ ) show no marked differences from newly hatched snail larvae $(-11.0 \pm 0.1 \%)$, suggesting that the snails were unable to consume Miscanthus sinensis at all. However, Stott (2002) reported a lower growth rate of snails cultured with dried sour orange tree leaves $\left(\mathrm{C}_{3}\right.$ plant $)$ compared to those cultured by lettuce and corn, suggesting food quality such as water content or physical structure as the reason for food preference. Regarding the land snail Acusta 
Table 3. Stable isotope results of snail individual fractions and the estimated contributions of their shell carbon sources.

\begin{tabular}{lrrrrr}
\hline Sample & Spirals & $\begin{array}{r}\text { Shell } \\
\text { (13 }(\%)\end{array}$ & & $y(\%)$ & $z(\%)$ \\
\hline S13_1 & $1-3$ & -8.2 & 64.6 & 20.2 & 15.2 \\
S13_2 & $3-4$ & -9.2 & 67.2 & 21.0 & 11.9 \\
S13_3 & $4-4.5$ & -9.3 & 67.5 & 21.1 & 11.4 \\
S13_4 & $4.5-5$ & -10.0 & 69.5 & 21.7 & 8.8 \\
\hline S19_1 & $1-3$ & -8.1 & 65.1 & 16.3 & 18.6 \\
S19_2 & $3-4$ & -9.0 & 67.8 & 16.9 & 15.3 \\
S19_3 & $4-4.5$ & -9.1 & 67.9 & 17.0 & 15.1 \\
S19_4 & $4.5-5$ & -9.2 & 68.1 & 17.0 & 14.9 \\
S19_5 & $5-5.5$ & -12.6 & 77.9 & 19.5 & 2.6 \\
\hline S25_1 & $1-3$ & -9.2 & 66.0 & 16.5 & 17.5 \\
S25_2 & $3-4$ & -10.8 & 70.6 & 17.6 & 11.8 \\
S25_3 & $4-4.5$ & -12.0 & 73.9 & 18.5 & 7.6 \\
S25_4 & $4.5-5$ & -12.4 & 75.0 & 18.8 & 6.2 \\
S25_5 & $5-5.5$ & -13.1 & 76.9 & 19.2 & 3.9 \\
\hline S31_1 & $1-3$ & -8.1 & 66.1 & 16.5 & 17.4 \\
S31_2 & $3-4$ & -9.2 & 69.4 & 17.3 & 13.3 \\
S31_3 & $4-4.5$ & -8.8 & 68.3 & 17.1 & 14.7 \\
S31_4 & $4.5-5$ & -10.8 & 74.0 & 18.5 & 7.5 \\
\hline S39_1 & $1-3$ & -9.1 & 66.7 & 17.1 & 16.2 \\
S39_2 & $3-4$ & -10.4 & 70.5 & 18.1 & 11.4 \\
S39_3 & $4-4.5$ & -11.4 & 73.5 & 18.9 & 7.6 \\
S39_4 & $4.5-5$ & -12.8 & 77.3 & 19.8 & 2.8 \\
\hline R & & & & \\
\hline
\end{tabular}

Relative culturing conditions are shown in Table 1.

Meanings of symbols $x, y$, and $z$ are the same as those shown in Table 1.

despecta, food preference has been reported by Suzuki and Yamashita (1967) and Takeuchi and Tamura (1995). For instance, this species were unable to eat Oxalis corniculata ( $\mathrm{C}_{3}$ plant), Commelina communis $\left(\mathrm{C}_{3}\right.$ plant), or Yoshinagella japonica (Fungi) at all. Similar phenomena have also been observed in nature. Hatziioannou et al. (1994) and Iglesias and Castillejo (1999) observed that land snails do not eat plant species arbitrarily. Baldini et al. (2007) reported that the feces of land snail Cerion collected from Sporobolus domingensis $\left(\mathrm{C}_{4}\right)$ plant exhibited $\delta^{13} \mathrm{C}$ values more typical of a $\mathrm{C}_{3}$ plant, suggesting a preference of $\mathrm{C}_{3}$ plant as food of these snails. However, some other studies, such as those of Yanes et al. (2013b), indicate an opposite conclusion. Their results show that individuals from the same land snail species consume different plants in relation to their relative abundance in nature. To summarize, we infer that the food selectivity of land snails might depend on species, which would increase the difficulty of their application in the paleoenvironment reconstruction, especially for the accurate study of $\mathrm{C}_{3} / \mathrm{C}_{4} \mathrm{veg}-$ etation distribution.

In addition, although some previous works reported that the fresh plants are the main diet for some land snail species (e.g., Suzuki and Yamashita, 1967; Colonese et al., 2014),
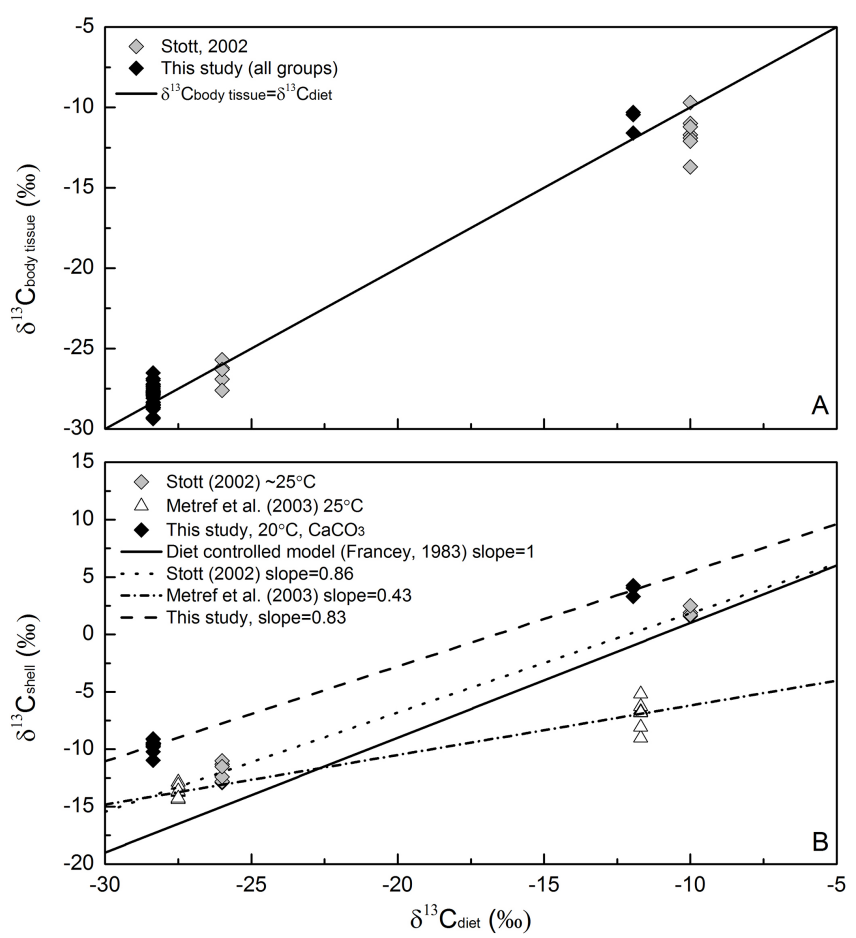

Figure 8. $\delta^{13} \mathrm{C}$ of snail body tissue against diet (a). $\delta^{13} \mathrm{C}$ of snail shell aragonite against diet (b).

it may not be common for all the species. According to the literature, land snails can eat decayed plant matter (Richardson, 1975), fungi, animal tissue (Mason, 1970), lichens (Baur et al., 1994) and other organic matter in nature. The consumed proportions of these food sources vary among land snail species (Mason, 1970).

Consequently, we suggest that pre-investigation of food preference on living snails is important before applying shell carbon isotopic values in the paleoenvironment reconstruction of a certain species. In addition, information from future studies of food quality's influence on snail shell $\delta^{13} \mathrm{C}$ values might be helpful too.

\subsubsection{Atmospheric $\mathrm{CO}_{2}$}

Although Stott (2002) and Metref et al. (2003) reported that atmospheric $\mathrm{CO}_{2}$ does not contribute to shell carbonate $\delta^{13} \mathrm{C}$ values based on culturing land snail Helix aspersa, some works clarify it as an important source of shell carbon. For instance, according to the combination of $\delta^{13} \mathrm{C}$ and ${ }^{14} \mathrm{C}$ values observed from modern land snail shells, Romaniello (2008) calculated the contribution of atmospheric $\mathrm{CO}_{2}$ varying from 16 to $48 \%$. McConnaughey and Gillikin (2008) summarized the previous studies of the relationship between land snail shell carbonate $\delta^{13} \mathrm{C}$ and shell organics (or body tissue organics / diet) and pointed out that the offsets are greater when the $\delta^{13} \mathrm{C}$ of organics diverge more from atmospheric $\mathrm{CO}_{2}$, i.e., when the slope of the shell vs. organic regression line is 
less than unity, suggesting that the latter does contribute to shell carbonate.

In this study, our calculation results revealed that atmospheric $\mathrm{CO}_{2}$ can affect shell carbonate isotopic values, and our estimated contributions are, respectively, 16-24\% (fed cabbage) and 18-20\% (fed corn). More clear evidence might be that, for snails developing without $\mathrm{CaCO}_{3}$ (Fig. 3), shell $\delta^{13} \mathrm{C}$ values became higher than the expected values controlled by one end member (diet). These estimated values can be attributed to two pathways: (1) atmospheric $\mathrm{CO}_{2}$ directly being introduced into the bicarbonate pool via respiration; (2) using the imbibed water as dissolved atmospheric $\mathrm{CO}_{2}$. The carbon isotope fractionation exhibits no difference between these two pathways.

However, because the $\mathrm{CO}_{2}$ concentration and its in situ carbon isotopic value were not monitored in the semi-sealed system, the $\mathrm{CO}_{2}$ accumulated gradually from the respiration of snails and plant tissues might affect the accuracy of our estimations of atmospheric $\mathrm{CO}_{2}$. Although Balakrishnan and Yapp (2004) inferred that the accumulated $\mathrm{CO}_{2}$ (ca. 240 ppm, vs. ambient background) produced by the respiration under forest canopy would contribute an insignificant amount of variation of shell $\delta^{13} \mathrm{C}$ values (ca. $0.1 \%$ ), we suggest that additional studies based on experimentation are needed. Furthermore, the limited accuracy of our assumption of similar diet/atmospheric $\mathrm{CO}_{2}$ ratio at the same temperature must be acknowledged because the snails have individual differences of metabolic rates during their growth (Barnhart and McMahon, 1987). Therefore, to learn more accurate contributions of atmospheric $\mathrm{CO}_{2}$, further incubation experiments are necessary, which are expected to include several parallel groups with ${ }^{14} \mathrm{C}$-labeled or $\delta^{13} \mathrm{C}$-different $\mathrm{CO}_{2}$ compositions, and also to record the concentration and isotopic composition variations of in situ atmospheric $\mathrm{CO}_{2}$ during cultivation.

\subsection{Metabolic rate}

Snail individuals have different metabolic rates in different environment conditions, or even in different growth phases of a single individual. Different metabolic rates reflect different partial pressures of $\mathrm{CO}_{2}$ produced from the diet, which consequently cause different flux ratios among $\mathrm{CO}_{2}$ produced from metabolism, digestion of limestone, and atmosphere to approach a carbon isotope steady state in snail body fluids, and which eventually produce different $\delta^{13} \mathrm{C}$ values. Much of the discussion we have presented above shows influences of this kind, such as (1) snails cultured at $30^{\circ} \mathrm{C}$ groups with $\mathrm{CaCO}_{3}$ show more-depleted $\delta^{13} \mathrm{C}$ values than those at 20 and $25^{\circ} \mathrm{C}$ groups (Fig. 6a). Correspondingly, they have a lower survival rate and lighter mass, suggesting stress from poor growth conditions (e.g., perishable leaves, lack of oxygen). (2) For one snail individual, the trend of a decrease in both $\delta^{13} \mathrm{C}$ values of shell carbonate (Fig. 7a) and the estimated contribution of ingested carbonate (Fig. $7 \mathrm{~b}$ ) reflect a decreasing metabolic rate along with snail development.

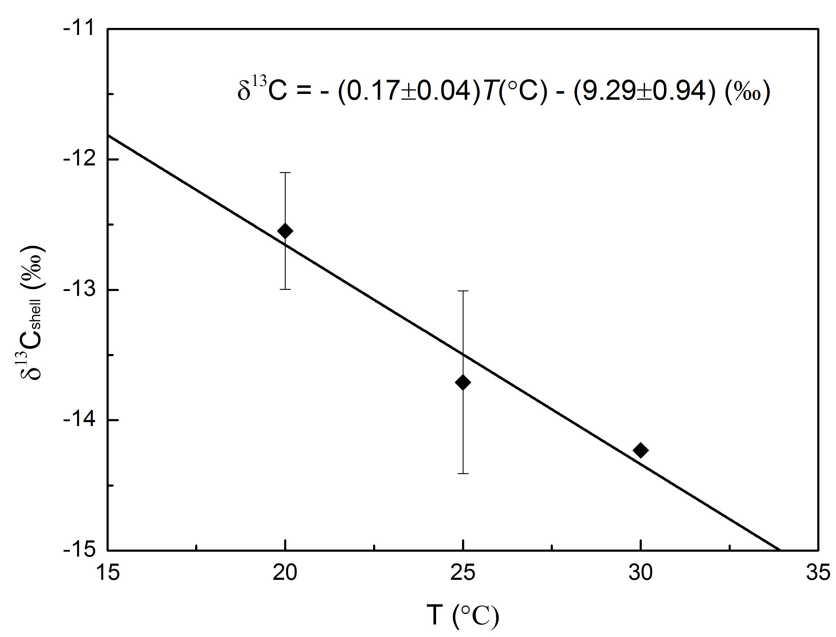

Figure 9. Relationship between $\delta^{13} \mathrm{C}$ of snail shell aragonite (fed without carbonate) and different culture temperatures.

(3) Also, the different slopes presented in Fig. 8b reveal different metabolic rates among different snail species or different cultivation conditions.

Therefore, the variations in metabolic rates attributable to the shift of environmental conditions, which can produce discrepancies of shell carbonate $\delta^{13} \mathrm{C}$ values, should be considered in paleoenvironment studies. For example, Yanes et al. (2011) reported $3 \%$ o higher moving average shell $\delta^{13} \mathrm{C}$ values during the glacial interval (ca. 50-15 ka BP) than today and inferred a larger proportion of $\mathrm{C}_{4}$ plant during that period. However, this study revealed that shell carbonate $\delta^{13} \mathrm{C}$ values of land snails, for those fed same diet (cabbage) and carbonate but maturing at different temperatures, can also vary as greatly as $3.5 \%$ (Fig. 6a).

Consequently, the carbon isotopic composition controlled by metabolic rate in land snail fossils can be regarded as an auxiliary tool for ascertaining changes of paleoenvironment conditions, such as suddenly changed environment conditions during the Younger Dryas event.

\subsection{Temperature}

Theoretically, temperature can affect the fractionation factor between gaseous $\mathrm{CO}_{2}$ and $\mathrm{HCO}_{3}^{-}$in land snail body fluid from a relationship presented as $\Delta^{13} \mathrm{C}_{\mathrm{HCO}_{3}-\mathrm{g}}=-$ $(0.114 \pm 0.003) T\left({ }^{\circ} \mathrm{C}\right)+(10.78 \pm 0.05) \%$ (Mook et al., 1974; Zhang et al., 1995; Szaran, 1997). Therefore, for shells precipitated at two temperatures, the discrepancy between $\delta^{13} \mathrm{C}$ values $\left(\Delta^{13} \mathrm{C}, \%\right.$ ) is $-0.11^{\circ} \mathrm{C}^{-1} \times T$ (Zhang et al., 1995; see also in Romanek et al., $1992,-0.13{ }^{\circ} \mathrm{C}^{-1}$ and Szaran, $\left.1997,-0.10^{\circ} \mathrm{C}^{-1}\right)$. We observed a relationship of $-0.17 \pm 0.04{ }^{\circ} \mathrm{C}^{-1}$ among snails fed without $\mathrm{CaCO}_{3}$ (Fig. 9), which is not significantly different from the theoretically expected relation. The small sharper trend might somehow reflect metabolic differences among the snails at 
different temperature conditions. The $\delta^{13} \mathrm{C}$ discrepancy of $0.17 \%{ }^{\circ} \mathrm{C}^{-1}$ is small compared with the contributions of different carbon sources. For that reason, no special consideration of environmental parameters of this kind is necessary on most occasions.

\subsection{Carbon isotopic fractionations during egg laying and hatching}

Metref et al. (2003) found that hatched and one-day-old snails showed $\delta^{13} \mathrm{C}$ values that were depleted by $2.5 \%$ compared to those of their parents. They inferred that shells of the hatching juveniles were built not only from eggshell calcite but also from isotopic-depleted albumen. We have observed these $\delta^{13} \mathrm{C}$ results for Acusta despecta sieboldiana: adult snails (parents), $-11.5 \pm 1.2 \%$ o $(n=6)$; hatched snails: $-11.0 \pm 0.1 \%$ o $(n>10$, mixed samples); eggs: $-13.1 \pm 0.9 \%$ o (two groups of eggs, for each group, $n>10$ ). No marked $\delta^{13} \mathrm{C}$ depletion was found between hatched snails and adults.

Romanek et al. (1992) pointed out that fractionation factors among calcite, $\mathrm{HCO}_{3}^{-}$, and aragonite are temperatureindependent when they are in equilibrium conditions. Their values were reported as $\Delta^{13} \mathrm{C}_{\text {Calcite- } \mathrm{HCO}_{3}^{-}}=0.9 \pm 0.2 \%$, $\Delta{ }^{13} \mathrm{C}_{\text {Aragonite- }} \mathrm{HCO}_{3}^{-}=2.7 \pm 0.2 \%, \quad \Delta^{13} \mathrm{C}_{\text {Aragonite-Calcite }}=$ $1.8 \pm 0.2 \%$ (Rubinson and Clayton, 1969; see also Romanek et al., 1992, $\Delta^{13} \mathrm{C}_{\text {Calcite- }} \mathrm{HCO}_{3}^{-}=1.0 \pm 0.2 \%$; $\Delta{ }^{13} \mathrm{C}_{\text {Aragonite- }-\mathrm{HCO}_{3}^{-}}=2.7 \pm 0.6 \% ; \quad \Delta{ }^{13} \mathrm{C}_{\text {Aragonite-Calcite }}=$ $1.7 \pm 0.4 \%$ ) . According to the XRD results, all of our cultured snail shells are made of aragonite, whereas eggshells are made of calcite. We are striving to ascertain the isotopic fractionations based on calcite- $\mathrm{HCO}_{3}^{-}$-aragonite equilibrium. At this isotopic equilibrium condition, (a) for the laying process: when the snail precipitates shell (aragonite) from bicarbonate pool, $\delta^{13} \mathrm{C}$ will enrich $2.7 \%$ and when it precipitates eggshell (calcite), $\delta^{13} \mathrm{C}$ will enrich 0.9 $1.0 \%$. Therefore, the difference between shell aragonite and eggshell calcite is expected to be 1.7-1.8\%o; we obtain a similar value of $1.6 \%$, suggesting that snail eggshells are also precipitated from the bicarbonate pool and that they follow the equilibrium fractionation. (b) For the hatching process, when the larvae are hatching, we assume that the shell calcite will dissolve gradually into the egg water to form a bicarbonate pool to precipitate egg aragonite. Then the fractionation between egg calcite and hatched snail shell aragonite is expected to be around -1.8 to $-1.7 \%$. Here we obtained a value of $-2.1 \%$, which is also consistent with the assumed value if we consider the measurement error, suggesting that the shell aragonite is transferred from eggshell calcite at an isotopic equilibrium condition.

\section{Conclusions}

From culturing the land snail Acusta despecta sieboldiana under controlled environments, we confirmed that diet, atmospheric $\mathrm{CO}_{2}$, and ingested limestone are important sources controlling shell carbon isotopic composition. We have also discussed the influences of metabolic rates. Furthermore, temperature can affect shell carbonate $\delta^{13} \mathrm{C}$ values by controlling the carbon isotopic fractionation of gaseous $\mathrm{CO}_{2}-$ bicarbonate equilibrium. We presented a simple but credible framework to assess the mechanisms of how each source and environmental parameter might affect shell carbonate $\delta^{13} \mathrm{C}$ values based on this and earlier studies. According to this framework and some reasonable assumptions, we estimated the contribution of different carbon sources for each snail individual: for cabbage-fed $\left(\mathrm{C}_{3}\right.$ plant $)$ snails, the contributions of diet, atmospheric $\mathrm{CO}_{2}$, and ingested limestone vary in the ranges of $66-80,16-24$, and $0-13 \%$, respectively. Furthermore, for corn-fed $\left(\mathrm{C}_{4}\right.$ plant $)$ snails, because of the potential food stress (less ability to consume $\mathrm{C}_{4}$ plants), the contributions vary in the ranges of 56-64, 18-20, and 16-26\%, respectively.

Secondly, results show that Acusta despecta sieboldiana discriminate in their choices of different plant species as food. For instance, they can grow faster when eating $\mathrm{C}_{3}$ plants such as cabbage compared with $\mathrm{C}_{4}$ plants such as corn, and they cannot eat certain $\mathrm{C}_{4}$ plants such as Miscanthus sinensis (no growth). This kind of food selectivity of land snails increases the difficulty of their application in the paleoenvironment reconstruction, especially for the accurate study of $\mathrm{C}_{3} / \mathrm{C}_{4}$ vegetation distribution. Finally, we inferred that during the egg laying and hatching of our cultured snails, carbon isotope fractionation is controlled only by the isotopic exchange of the calcite- $\mathrm{HCO}_{3}^{-}$-aragonite equilibrium.

To initiate the application of carbon isotopes for paleoenvironment reconstruction, additional work should be undertaken in future culture experiments, especially in the following aspects: (1) intra-shell measurements of snails fed with $\mathrm{C}_{4}$ plants and those fed without $\mathrm{CaCO}_{3}$ should be taken in future studies to verify the phenomenon of decreasing trend of shell $\delta^{13} \mathrm{C}$ along with the snail growth direction; (2) influences of food quality such as water contents or physical structure on snail shell $\delta^{13} \mathrm{C}$ values should be investigated; (3) snails should be cultured in air with ${ }^{14} \mathrm{C}$-labeled or $\delta^{13} \mathrm{C}$ different $\mathrm{CO}_{2}$ compositions to ascertain the contribution of atmospheric $\mathrm{CO}_{2}$ more accurately; (4) snails fed with $\mathrm{C}_{4}$ plants under a non-carbonate condition should be evaluated; (5) more land snail species preferring varied environmental conditions should be studied to ascertain which inferences are common to all species and which are particular for a given species.

The Supplement related to this article is available online at doi:10.5194/bg-11-5335-2014-supplement. 
Acknowledgements. This study was supported by a Grant-in-Aid for Scientific Research (\#23224013) and a grant for the Global COE Program "From the Earth to Earths" to Tokyo Institute of Technology. We thank Kazunori Hasegawa for helping us ascertain the species of cultured land snails and Takuma Haga for helping us identify the growth stage of new generation. We thank Yingying Cheng for helping us run XRD measurements. Furthermore, our appreciation is extended to Xueqin Chi for her kind help during our cultivation of land snails. Finally, we are very grateful to Alexis Gilbert for his helpful comments.

Edited by: D. Gillikin

\section{References}

Azuma, M.: Land Snails of Japan, Hoikusha Publishing Co., Osaka, 1995.

Balakrishnan, M. and Yapp, C. J.: Flux balance models for the oxygen and carbon isotope compositions of land snail shells, Geochim. Cosmochim. Acta, 68, 2007-2024, 2004.

Baldini, L. M., Walker, S. E., Railsback, L. B., Baldini, J. U., and Crowe, D. E.: Isotopic ecology of the modern land snail Cerion, San Salvador, Bahamas: Preliminary advances toward establishing a low-latitude island paleoenvironmental proxy, Palaios, 22, 174-187. 2007.

Balslev-Clausen, D., Dahl, T. W., Saad, N., and Rosing, M. T.: Precise and accurate $\delta^{13} \mathrm{C}$ analysis of rock samples using Flash Combustion-Cavity Ring Down Laser Spectroscopy, J. Anal. Atmos. Spectrom., 28, 516-523, 2013.

Barnhart, M. C. and McMahon, B. R.: Discontinuous carbon dioxide release and metabolic depression in dormant land snails, J. Exp. Biol., 128, 123-138, 1987.

Baur, A., Baur, B., and Fröberg, L.: Herbivory on calcicolous lichens: different food preferences and growth rates in two coexisting land snails, Oecologia, 98, 313-319, 1994.

Colonese, A. C., Zanchetta, G., Fallick, A. E., Martini, F., Manganelli, G., and Lo-Vetro, D.: Stable isotope composition of Late Glacial land snail shells from Grotta del Romito (Southern Italy): palaeoclimatic implications, Palaeogeogr. Palaeocl., 254, 550560, 2007.

Colonese, A. C., Zanchetta, G., Fallick, A. E., Martini, F., Manganelli, G., and Drysdale, R. N.: Stable isotope composition of Helixligata (Müller, 1774) from Late Pleistocene-Holocene archaeological record from Grotta della Serratura (Southern Italy): Palaeoclimatic implications, Global Planet Change, 71, 249-257, 2010.

Colonese, A. C., Zanchetta, G., Drysdale, R. N., Fallick, A. E., Manganelli, G., Lo-Vetro, D., Martini, F., and Di Giuseppe, Z.: Stable isotope composition of Late Pleistocene-Holocene Eobaniavermiculata (Müller, 1774) (Pulmonata, Stylommatophora) shells from the Central Mediterranean Basin: Data from Grotta d'Oriente (Favignana, Sicily), Quatern. Int., 244, 76-87, 2011.

Colonese, A. C., Zanchetta, G., Fallick, A. E., Manganelli, G., Lo Cascio, P., Hausmann, N., Baneschi, I., and Regattieri, E.: Oxygen and carbon isotopic composition of modern terrestrial gastropod shells from Lipari Island, Aeolian Archipelago (Sicily), Palaeogeogr. Palaeocl., 394, 119-127, 2014.
Coplen, T. B., Brand, W. A., Gehre, M., Gröning, M., Meijer, H. A., Toman, B., and Verkouteren, R. M.: New guidelines for $\delta^{13} \mathrm{C}$ measurements, Anal. Chem., 78, 2439-2441, 2006.

DeNiro, M. J. and Epstein, S.: Influence of diet on the distribution of carbon isotopes in animals, Geochim. Cosmochim. Acta, 42, 495-506, 1978.

Egonmwan, R. I.: Effects of dietary calcium on growth and oviposition of the African land snail Limicolariaflammea (Pulmonata: Achatinidae), Rev. Biol. Trop., 56, 333-343, 2008.

Francey, R. J.: A comment on ${ }^{13} \mathrm{C} /{ }^{12} \mathrm{C}$ in land snail shells, Earth Planet. Sci. Lett., 63, 142-143, 1983.

Fujie, A.: Holocene fossil assemblages of minute land molluscs from sand dunes on Kikaijima Island in the Amami Archipelago, Japan, Jpn. J. Malacol., 59, 317-324, 2000a (in Japanese).

Fujie. A.: The late Pleistocene fossil assemblages of minute land molluscs from an ancient sand dune on Kikaijima Island in the Amami Archipelago, Jpn. J. Malacol., 59, 165-175, 2000b (in Japanese).

Goodfriend, G. A.: The use of land snail shells in paleoenvironmental reconstruction, Quaternary Sci. Rev., 11, 665-685, 1992.

Goodfriend, G. A. and Ellis, G. L.: Stable carbon and oxygen isotopic variations in modern Rabdotus land snail shells in the southern Great Plains, USA, and their relation to environment, Geochim. Cosmochim. Acta, 66, 1987-2002, 2002.

Goodfriend, G. A. and Hood, D. G.: Carbon isotope analysis of land snail shells; implications for carbon sources and radiocarbon dating, Radiocarbon, 25, 810-830, 1983.

Goodfriend, G. A. and Magaritz, M.: Carbon and oxygen isotope composition of shell carbonate of desert land snails, Earth Planet. Sci. Lett., 86, 377-388, 1987.

Goodfriend, G. A. and Stipp, J. J.: Limestone and the problem of radiocarbon dating of land-snail shell carbonate, Geology, 11, 575-577, 1983.

Goodfriend, G. A., Magaritz, M., and Gat, J. R.: Stable isotope composition of land snail body water and its relation to environmental waters and shell carbonate, Geochim. Cosmochim. Acta, 53, 3215-3221, 1989.

Hatziioannou, M., Eleutheriadis, N., and Lazaridou-Dimitriadou, M.: Food preferences and dietary overlap by terrestrial snails in Logos area (Edessa, Macedonia, Northern Greece), J. Mollus. Stud., 60, 331-341, 1994.

Iglesias, J. and Castillejo, J.: Field observations on feeding of the land snail Helix aspersa Müller, J. Mollus. Stud., 65, 411-423, 1999.

Keeling, R. F., Piper, S. C., Bollenbacher, A. F., and Walker, S. J.: Monthly atmospheric ${ }^{13} \mathrm{C} /{ }^{12} \mathrm{C}$ isotopic ratios for $11 \mathrm{SIO}$ stations, in: Trends: A Compendium of Data on Global Change, Carbon Dioxide Information Analysis Center, Oak Ridge National Laboratory, US Department of Energy, Oak Ridge, Tenn., USA, 2010.

Kehrwald, N. M., McCoy, W. D., Thibeault, J., Burns, S. J., and Oches, E. A.: Paleoclimatic implications of the spatial patterns of modern and LGM European land-snail shell $\delta^{18} \mathrm{O}$, Quaternary Res., 74, 166-176, 2010.

Kohno, M.: Rearing of SIEBOLD's globular snail Acusta despecta (SOWERBY) on a semi-synthetic diet, Jpn. J. Malacol., 35, 5062, 1976 (in Japanese).

Lécolle, P.: The oxygen isotope composition of landsnail shells as a climatic indicator: applications to hydrogeology and paleoclimatology, Chem. Geol., 58, 157-181, 1985. 
Lee, J.-S. and Kwon, O.-K.: Studies on the intraspecific variations on geological distributions of Acusta despecta sieboldiana in Korea, Korean J. Malacol., 12, 19-31, 1996 (in Korean).

Mason, C. F.: Food, feeding rates and assimilation in woodland snails, Oecologia, 4, 358-373, 1970.

McConnaughey, T. A. and Gillikin, D. P.: Carbon isotopes in mollusk shell carbonates, Geo.-Mar. Lett., 28, 287-299, 2008.

Metref, S., Rousseau, D. D., Bentaleb, I., Labonne, M., and VianeyLiaud, M.: Study of the diet effect on $\delta^{13} \mathrm{C}$ of shell carbonate of the land snail Helixaspersa in experimental conditions, Earth Planet. Sci. Lett., 211, 381-393, 2003.

Mook, W. G., Bommerson, J. C., and Staverman, W. H.: Carbon isotope fractionation between dissolved bicarbonate and gaseous carbon dioxide, Earth Planet. Sci. Lett., 22, 169-176, 1974.

Okuma, R.: Mating season of two land snails, Bradybaena similaris and Acusta sieboldiana, Chiribotan, 13, 51-59, 1982 (in Japanese).

Pigati, J. S., Quade, J., Shahanan, T. M., and Haynes Jr., C. V.: Radiocarbon dating of minute gastropods and new constraints on the timing of late Quaternary spring-discharge deposits in southern Arizona, USA, Palaeogeogr. Palaeocl., 204, 33-45, 2004.

Pigati, J. S., Rech, J. A., and Nekola, J. C.: Radiocarbon dating of small terrestrial gastropod shells in North America, Quat. Geochronol., 5, 519-532, 2010.

Richardson, A. M. M.: Food, feeding rates and assimilation in the land snail Cepaea nemoralis L., Oecologia, 19, 59-70, 1975.

Romanek, C. S., Grossman, E. L., and Morse, J. W.: Carbon isotopic fractionation in synthetic aragonite and calcite: effects of temperature and precipitation rate, Geochim. Cosmochim. Acta, 56, 419-430, 1992.

Romaniello, L., Quarta, G., Mastronuzzi, G., D’Elia, M., and Calcagnile, L.: ${ }^{14} \mathrm{C}$ age anomalies in modern land snails shell carbonate from Southern Italy, Quat. Geochronol., 3, 68-75, 2008.

Rubinson, M. and Clayton, R. N.: Carbon-13 fractionation between aragonite and calcite, Geochim. Cosmochim. Acta, 33, 9971002, 1969.

Stott, L. D.: The influence of diet on the $\delta^{13} \mathrm{C}$ of shell carbon in the pulmonate snail Helixaspersa, Earth Planet. Sci. Lett., 195, 249-259, 2002.

Sumikawa, S.: The life cycle of Acusta despecta sieboldiana PFEIFFER observed in Northern Kyushu, Doubutsugaku Zasshi, 71, 365 pp., 1962 (in Japanese).

Suzuki, M. and Yamashita, Y.: On the food plants of Siebold's globular snail, Acusta despecta Gray (Gastropoda, Mollusca), Memoirs of the Institute of Sciences and Technology, Meiji University, 6, 211-227, 1967 (in Japanese).

Szaran, J.: Achievement of carbon isotope equilibrium in the system $\mathrm{HCO}_{3}^{-}$(solution)- $\mathrm{CO}_{2}$ (gas), Chem. Geol., 142, 79-86, 1997.

Takahashi, K., Asakura, A. and Kurozumi, T.: Copulation frequency and mating system of the land snail Acusta despecta sieboldiana (Pfeiffer), Jpn. J. Malacol., 51, 323-326, 1992 (in Japanese).

Takamiya, H. and Meighan, C. W.: Faunal remains obtained from the Atta-baru Shell Midden, Bulletin of the Department of Sociology, Okinawa International University, 19, 195-207, 1992 (in Japanese).

Takeuchi, M. and Tamura, M.: Seasonal occurrence, daily activity and food utilization of three sympatric terrestrial Gas- tropods, House and Household Insect Pests, 17, 11-23, 1995 (in Japanese).

Wahl, E. H., Fidric, B., Rella, C. W., Koulikov, S., Kharlamov, B., Tan, S., Kachanov, A. A., Richman, B. A., Crosson, E. R., Paldus, B. A., Kalaskar, S., and Bowling, D. R.: Applications of cavity ring-down spectroscopy to high precision isotope ratio measurement of ${ }^{13} \mathrm{C} /{ }^{12} \mathrm{C}$ in carbon dioxide, Isot. Environ. Healt. S., 42, 21-35, 2006.

Yanes, Y., Delgado, A., Castillo, C., Alonso, M. R., Ibáñez, M., Dela-Nuez, J., and Kowalewski, M.: Stable isotope $\left(\delta^{18} \mathrm{O}, \delta^{13} \mathrm{C}\right.$, and $\delta \mathrm{D})$ signatures of recent terrestrial communities from a lowlatitude, oceanic setting: endemic land snails, plants, rain, and carbonate sediments from the eastern Canary Islands, Chem. Geol., 249, 377-392, 2008a.

Yanes, Y., Tomašových, A., Kowalewski, M., Castillo, C., Aguirre, J., Alonso, M. R., and Ibáñez, M.: Taphonomy and compositional fidelity of Quaternary fossil assemblages of terrestrial gastropods from carbonate-rich environments of the Canary Islands, Lethaia., 41, 235-256, 2008 b.

Yanes, Y., Romanek, C. S., Delgado, A., Brant, H. A., Noakes, J. E., Alonso, M. R., and Ibáñez, M.: Oxygen and carbon stable isotopes of modern land snail shells as environmental indicators from a low-latitude oceanic island, Geochim. Cosmochim. Acta, 73, 4077-4099, 2009.

Yanes, Y., Yapp, C. J., Ibáñez, M., Alonso, M. R., De-la-Nuez, J., Quesada, M. L., Castillo, C., and Delgado, A.: PleistoceneHolocene environmental change in the Canary Archipelago as inferred from the stable isotope composition of land snail shells, Quaternary Res., 75, 658-669, 2011.

Yanes, Y., Gutiérrez-Zugasti, I., and Delgado, A.: Late-glacial to Holocene transition in northern Spain deduced from land-snail shelly accumulations, Quaternary Res., 78, 373-385, 2012.

Yanes, Y., García-Alix, A., Asta, M. P., Ibáñez, M., Alonso, M. R., and Delgado, A.: Late Pleistocene-Holocene environmental conditions in Lanzarote (Canary Islands) inferred from calcitic and aragonitic land snail shells and bird bones, Palaeogeogr. Palaeocl., 378, 91-102, 2013a.

Yanes, Y., Asta, M. P., Ibáñez, M., Alonso, M. R., and Romanek, C. S.: Paleoenvironmental implications of carbon stable isotope composition of land snail tissues, Quaternary Res., 80, 596-605, 2013b.

Yanes, Y., Riquelme, J. A., Cámara, J. A., and Delgado, A.: Stable isotope composition of middle to late Holocene land snail shells from the Marroquíes archeological site (Jaén, Southern Spain): Paleoenvironmental implications, Quatern. Int., 302, $77-$ 87, 2013c.

Yapp, C. J.: Oxygen and carbon isotope measurements of land snail shell carbonate, Geochim. Cosmochim. Acta, 43, 629-635, 1979.

Zaarur, S., Olack, G., and Affek, H. P.: Paleo-environmental implication of clumped isotopes in land snail shells, Geochim. Cosmochim. Acta, 75, 6859-6869, 2011.

Zanchetta, G., Leone, G., Fallick, A. E., and Bonadonna, F. P.: Oxygen isotope composition of living land snail shells: Data from Italy, Palaeogeogr. Palaeocl., 223, 20-33, 2005.

Zhang, J., Quay, P. D., and Wilbur, D. O.: Carbon isotope fractionation during gas-water exchange and dissolution of $\mathrm{CO}_{2}$, Geochim. Cosmochim. Acta, 59, 107-114, 1995. 